\title{
OBSERVATIONS ON THE GLACIERS OF THE RUWENZORI
}

\author{
By J. B. Whitтow
}

(Department of Geography, University of Reading, England)

\section{A. SHEPHERd}

(Department of Geography, University of Hong Kong, Hong Kong)

J. E. Goldthorpe

(Department of Sociology, Makerere University College, Uganda)

and P. H. TEMPLE

(Department of Geography, Makerere University College, Uganda)

\begin{abstract}
The glaciological work of six expeditions from Makerere University College to the Ruwenzori between December 1957 and July 1961 is described and some results are given.

The history of glaciological research in the Ruwenzori mountain range is outlined and the present ice distribution is described. A variety of evidence is presented to illustrate the pattern of change over the last 50 years, and all the glaciers examined are shown to have been drastically reduced in size, with an apparent acceleration in melting since the I940's. Six glaciers are known to have disappeared completely, whilst several others have split into smaller units.

A detailed survey of the Speke Glacier on Mount Speke was made, and calculations show that if the present trends continue all the ice below 4,573 m. on Mount Speke can be expected to disappear within the next 40 years.

The Elena and Savoia Glaciers on Mount Stanley and the Moore Glacier on Mount Baker are described, and recessional rates for each glacier are calculated. Measurements of the ice movement of the Elena Glacier demonstrate that it is still a fairly active glacier, although the Moore Glacier is thought to be completely stagnant. Other scientific measurements of glaciological significance include subglacial temperatures for the Elena Glacier, melt-water flow rates from the Speke Glacier and solar radiation measurements for several
\end{abstract} stations near the Ruwenzori ice margins.

RÉsumé. On décrit le travail glaciologique et on donne quelques résultats de 6 expéditions de "Makerere University College" au Ruwenzori entre décembre 1957 et juillet 1961 .

On souligne l'histoire de la recherche glaciologique dans la chaîne du Ruwenzori et on décrit l'actuelle distribution de glace. Plusieurs évidences illustrent le caractère du changement au cours des dernières $5^{\circ}$ années, et tous les glaciers examinés montrent une diminution très sensible de leurs dimensions, avec un accroissement apparent de la fusion depuis 1940. Six glaciers ont complètement disparu tandis que plusieurs autres se sont partagés en unités plus petites.

Une étude détaillée du glacier Speke (sur le mont Speke) a été faite, et les calculs montrent que si la tendance actuelle se confirme, on peut s'attendre à ce que toute la glace du mont Speke située en-dessous de $4573 \mathrm{~m}$ disparaisse dans les prochaines 40 années.

Les glaciers Elena et Savoia sur le mont Stanley et le glacier de Moore sur le mont Baker sont décrits et leur taux de récession calculé. La mesure du mouvement de la glace montre que le glacier Elena est encore un glacier assez actif, bien que l'on pense que le glacier de Moore soit complètement immobile. Les autres observations scientifiques à caractère glaciologique concernent les températures sub-glaciaires pour le glacier Elena, le débit d'eau de fusion du glacier Speke et la radiation solaire en plusieurs stations en bordure de la glace du Ruwenzori.

Zusammenfassung. Die glaziologischen Arbeiten von 6 Expeditionen des Makerere Universität-Kolleges zum Ruwenzori zwischen Dezember 1957 und Juli 1961 werden beschrieben und einige Resultate mitgeteilt. Die Geschichte der Gletscherforschung in der Ruwenzori-Kette wird auseinandergesetzt, die gegenwärtige Eisverteilung wird beschrieben. Verschiedene Beweise werden vorgeführt, um die Reihe der Veränderungen in den letzten 5o Jahren zu illustrieren. Es wird gezeigt, dass alle untersuchten Gletscher sich in ihrer Grösse sehr stark verändert haben; eine offensichtliche Beschleunigung der Abschmelzung ist seit 1940 eingetreten. Es ist bekannt, dass sechs Gletscher vollständig verschwunden sind, während andere Gletscher sich in kleinere Einheiten aufgesplittert haben.

Eine eingehende Aufnahme des Speke-Gletschers am Mount Speke wurde durchgeführt. Aus Berechnungen geht hervor, dass alles Eis unterhalb $4573 \mathrm{~m}$ am Mount Speke innerhalb der nächsten 40 Jahre verschwunden sein wird, wenn die jetzige Tendenz anhält.

Der Elena- und Savoia-Gletscher am Mount Stanley und der Moore-Gletscher am Mount Baker werden beschrieben, die Rückzugsbeträge für beide Gletscher werden berechnet. Eisgeschwindigkeitsmessungen am Elena-Gletscher zeigen, dass er noch ein ziemlich aktiver Gletscher ist, obwohl man der Meinung ist, dass der Moore-Gletscher vollständig stagniert. Andere wissenschaftliche Messungen von glaziologischer Bedeutung schliessen Temperaturmessungen im Eisinneren des Elena-Gletschers ein, ferner Schmelzwasserabflussmengen vom Speke-Gletscher und Sonnenstrahlungsmessungen für verschiedene Stationen in der Nähe der Ruwenzori-Eisränder. 


\section{INTRODUCTION}

The Ruwenzori are in reality a mountain range on the borders of Uganda and the Congo, and are thought to be the "Mountains of the Moon" referred to by the ancient Egyptians. Lying slightly north of the Equator in the western arm of the East African rift valley, the range is $95.5 \mathrm{~km}$. long and has a maximum breadth of $4^{8} \mathrm{~km}$. The Ruwenzori can be subdivided into six ice-capped mountains and several lower peaks which are periodically snowcovered. Of the ten peaks which rise above $4,878 \mathrm{~m}$. all but one are on Mount Stanley which claims the highest point, Margherita Peak (5, I I I m.). The six largest mountains are separated by passes, the average elevation of which is $4,268 \mathrm{~m}$., and by deeply incised valleys.

Unlike the other snow peaks of East Africa, the range is not of volcanic origin but is a gigantic uplifted horst, the origin of which is connected with the complex tectonics of the rift valley. Whereas the peripheral areas are composed of Archaean gneisses and mica-schists, the centre of the range consists of amphibolites, diorites, diabases and granites; this fact coupled with steep dips and vertical fractures is responsible for the existence and separation of the higher summits.

The permanent snow line stands at almost $4,573 \mathrm{~m}$. on the Uganda slopes and $4,75^{\circ} \mathrm{m}$. on the Congo slopes, although there is evidence of an earlier glaciation down to $2,134 \mathrm{~m}$. on the eastern slopes.

Six expeditions have been organized by Makerere University College to study the glaciers of the Ruwenzori range. Five of these expeditions were planned as a direct contribution to the I.G.Y. programme and four of them were led by F. P. Henderson (Department of Geology, Makerere University College). The first expedition (December 1957-January 1958) conducted a general reconnaissance of the area to assess the possibilities of glaciological investigations and also established a second bivouac hut at 4,5 I I m. close to the Elena Glacier which was to serve as an advance base for later work. Four further expeditions followed (June I958; December I958-January I959; June-July I959; December I959-January I960) at sixmonthly intervals and the last, after a gap of r 8 months, was in June-July r 961 . These times were planned to take advantage of the less rainy season in the Ruwenzori. Each expedition was formed largely from staff members of Makerere University College and lasted two to three weeks. Each expedition followed approximately the same pattern, the parties generally dividing themselves between a base camp at Bujuku hut $(3,963 \mathrm{~m}$.) and an advance base at the Elena bivouac huts $(4,5 \mathrm{I}$ I $\mathrm{m}$.). This enabled detailed observations over a considerable period to be made on the behaviour of the two major glaciers of the Uganda side, namely, the Speke Glacier and the Elena Glacier. Reconnaissance work was also done on other parts of the range: on Mount Baker in June $195^{8}$ and June 196r, on Mounts Emin and Gessi in July r959, on Mount Luigi di Savoia in January r96o and on the Savoia Glacier of Mount Stanley in June I96I. Preliminary accounts of much of this work have already been published (Makerere College Ruwenzori Expedition, r958 [a], [b], I959). This paper summarizes the glaciological work of these expeditions but a considerable mass of detailed information on this and related topics still remains to be worked over.

\section{Glaciological Investigations Prior to $195^{8}$}

The earliest evidence of value in the glaciological field was provided by photographs of some of the glaciers on the western slopes of the Ruwenzori which were seen in I89 I by Stuhlmann (1894) but were not recognized by him as actual glaciers. It was not until the ascent by J. E. S. Moore in 1900 that the existence of genuine glaciers was confirmed. Moore (I gor) made it quite clear in the account of his climb that the glacier he ascended from the upper Mobuku valley was the one now known as the Baker Glacier. For some reason, recent descriptions of Moore's climb have linked his name with the glacier at the northernmost end of the upper Mobuku valley, and it is the latter glacier (originally termed the "Mobuku Glacier" by the Duke of the Abruzzi) which is now called the Moore Glacier. Between Igoo 
and I906 several parties (Johnston, 1902; Fisher, 1905; Freshfield, 1906) ascended the "Mobuku [Moore] Glacier", including two members of the British Museum party, who also traversed the hanging glacier which separates Moore Peak from Wollaston Peak (Wollaston, I g08). So far as is known, apart from recording the position of the glaciers around the head of the Mobuku valley, nothing else of glaciological significance was recorded by any of these early explorers.

The first serious attempt to explore, identify and ascend the highest summits came in I 9o6, when a large-scale expedition, led by the Duke of the Abruzzi, provided a wealth of glaciological material (Filippi, I908). Although the highest summits had previously been described as snow-capped, earlier explorers had failed to realize the existence of six separate glacier complexes on the following mountains:

$\begin{array}{lc} & \begin{array}{c}\text { Height } \\ \text { m. }\end{array} \\ \text { Mount Stanley } & 5, \text { I I I } \\ \text { Mount Speke } & 4,89 \text { I } \\ \text { Mount Baker } & 4,873 \\ \text { Mount Emin } & 4,802 \\ \text { Mount Gessi } & 4,769 \\ \text { Mount Luigi di Savoia } & 4,665\end{array}$

The Abruzzi expedition identified about 30 glaciers, 2 I of which were named. The majority of the unnamed glaciers were those situated on the Congo slopes of Mount Stanley. Photographs of many of the glaciers taken in I 906 have proved invaluable for purposes of comparison with more recent photographs.

In addition to mapping and describing the major glaciers, the 1906 expedition recorded numerous signs of an earlier glaciation extending down to the plain of Ibanda at about $\mathrm{I}, 373 \mathrm{~m}$. This figure is of interest in that it represents the lowest altitude at which signs of glaciation have been reported in East Africa. It appears to be based on the presence of supposed erratics on the plain of Ibanda, although Roccati (the geologist of the expedition) admitted that they may not be the result of direct glacial transportation. More definite evidence of the presence of ice in the lower Mobuku valley was provided by the discovery in 1906 of the large Nyabitaba moraine, the base of which stands at 2, I34 m. It was calculated that in 1906 the existing glaciers extended down to about $3,84 \mathrm{I} \mathrm{m}$., although no mention was made of any particular locality. Roccati briefly described the characteristics of the glaciers at the time and stated that the permanent snow line lay between 4,070 and 4, I I $6 \mathrm{~m}$. He was also of the opinion that the rate of movement of the glaciers was slight, and that all the Ruwenzori glaciers were in a state of rapid retreat.

No other work of glaciological significance was carried out on the Ruwenzori for more than 40 years, although the first flight over the mountains by Humphreys in 193 I proved conclusively that there were no ice peaks other than those already known. In July i 932 , a Belgian expedition to study the natural history of the Congo slopes of the Ruwenzori took photographs of the glaciers which descend the western slopes of the Mount Stanley massif, and these allow a useful comparison to be made not only with recent photographs but also with those taken by Stuhlmann in I891 and Chapin in 1927 (Chapin, 1927). This 1932 party, led by Grunne (1937), estimated that the snow line stood at $4,45^{\mathrm{I}} \mathrm{m}$. on the Congo side of the Ruwenzori. Another minor but nevertheless valuable piece of glaciological evidence recorded about this time was when Synge (1937) ascended the Nyamgasani valley in 1935 and noted lateral moraines extending down to about $2,743 \mathrm{~m}$. His book also shows two interesting photographs of the rarely visited Thomson Glacier snout on the southern slopes of Mount Luigi di Savoia. 
In $1937-3^{8}$ a party of German mountaineers made a number of important climbs on the ice peaks of the Ruwenzori, and they produced the first contoured map of the central group (Mount Stanley, Mount Baker and Mount Speke) at a scale of I : 25,00o (Stumpp, 1952). Although none of the Congo glaciers of Mount Stanley are included, all the Mount Baker glaciers are shown, in addition to the Speke and Johnston Glaciers of Mount Speke. This map, with its $25 \mathrm{~m}$. contour interval and its clearly demarcated glaciers, is an invaluable aid to an understanding of the configuration of the major glaciers at a time almost midway between the Abruzzi expedition of 1906 and the more detailed glaciological studies of the 1950's.

In December 1949, the first detailed survey of any of the individual Ruwenzori glaciers was carried out on the Speke Glacier and the glacier snout was calculated to stand at an elevation of $4,237 \mathrm{~m}$. A brief description of the snout and ice conditions prevailing on the Speke and Elena Glaciers during this 1949 survey was given by Menzies (195I[a]) who recorded his observations ". . . in the hope that they may fill in some gaps and initiate a fuller enquiry". His account of the Ruwenzori ice-crystal structure was the first recorded. A photograph of the Speke Glacier snout is contained in another article by Menzies (195I[b]). It is noteworthy that, when describing the Elena Glacier in 1949, Menzies wrote that the "... snout of the glacier terminates at I 4,800 feet" (4,5 I I m.). Either the glacier advanced considerably between 1949 and 1952 , or the earlier calculation was in error, since the British Ruwenzori Expedition of $195^{2}$ showed that the Elena Glacier snout stood at approximately $4,420 \mathrm{~m}$.

Much valuable information concerning the western glaciers of Mount Stanley resulted from the visit of Heinzelin (1955) to the Ruwenzori in July 1950. The Alexandra, West Stanley, Moebius and West Elena Glaciers were examined and evidence of recent retreat was found to be extensive. In addition to a detailed account of the recession of the West Stanley Glacier, Heinzelin ([1952[a]]) noted the diverse periglacial phenomena of the western slopes.

The British Ruwenzori Expedition of July 1952, although largely concerned with a geological examination, provided the most valuable glaciological data so far collected (Bergström, i 955). The glaciologist of the expedition, Bergström, collaborated with Heinzelin and Menzies who were also in the Ruwenzori at that time, and a detailed examination on several of the Mount Stanley Glaciers was carried out.

Much of the time was devoted to a survey of the Elena Glacier and the budget of this glacier was also computed. A contour map of the glacier was made and the characteristics and stratification of the ice were noted in some detail. A series of markers was erected down the centre of the glacier, but unfortunately, so far as is known, they were not utilized in any subsequent resurvey. It will be noted elsewhere in this report that only one of the $195^{2}$ markers survived until January $195^{8}$, and even this was of no use for measurement purposes. A number of important weather observations were recorded over a period of three weeks on the Elena Glacier; these were the first significant meteorological readings from the high peaks of the Ruwenzori since the Abruzzi expedition of rgo6. The West Stanley Glacier was also studied, and in this case a comparison was possible between recent photographs and those taken by earlier expeditions.

In addition to studying the ice, several moraines were mapped, particularly those below the snout of the Elena Glacier, and the rate of glacial recession was estimated. The front of the Elena Glacier was found to have retreated $100 \mathrm{~m}$. between 1900 and 1920 , and a similar distance between 1932 and 1952. It was believed that on the Congo slopes there were no moraines below $3,800 \mathrm{~m}$., whereas on the Uganda side it was thought that there was evidence of a former glaciation down to about $2,000 \mathrm{~m}$. Calculations showed that in 1952 glaciers on the Uganda slopes (Elena Glacier ?) descended to about $4,400 \mathrm{~m}$., although it is probable that the Moore Glacier (which was not visited by the $195^{2}$ expedition) then descended to approximately $4,192 \mathrm{~m}$. The stratigraphy in the mud at certain lake sites was also examined and an attempt was made to correlate the ancient shore-lines with oscillations of the glaciers. 
Since the British Ruwenzori Expedition there has been very little glaciological investigation on the mountains, although H. A. Osmaston, of the Uganda Forestry Department, has visited the glaciers on several occasions; in August 1953 he reported that at one point the front of the Elena Glacier had advanced at least $2 \mathrm{~m}$. in a year.

Certain discrepancies on the map in the area of the Savoia and Elena Glaciers were investigated in January 1953 by Busk (1954), and he proved conclusively that the Savoia Glacier did not have its origin on the Savoia Peak. He examined the higher reaches of the prominent hanging glacier west of the Elena Glacier, and named it the Coronation Glacier.

In December I955, J. Smith and T. E. Fletcher, on a climbing expedition to the Ruwenzori, made a valuable contribution to the study of the Elena Glacier budget by obtaining a profile of the firn at $4,847 \mathrm{~m}$. on the Stanley Plateau. In addition, photographs were taken of the Speke, Margherita and East Stanley Glaciers.

Heinzelin revisited the Congo slopes of Mount Stanley in January 1956 but on this occasion his research was primarily of a biological nature (Heinzelin and Mollaret, I956). Nevertheless, the moraines and glacial lakes in the vicinity of the West Stanley and Moebius Glaciers were examined and mapped in great detail.

Thus, by $195^{8}$ all the Ruwenzori glaciers had been seen, although many of them had not been named or visited. In conclusion, it might be said that the exploration and description of the Ruwenzori glaciers can be grouped into three periods: $189 \mathrm{I}-\mathrm{I} 906$, the earliest explorations, usually by large-scale expeditions (British Museum, Abruzzi); 1907-45, an interim period during which there was virtually no important glaciological work done, although Humphreys made useful explorations; $1946-58$, which saw the well-equipped scientific expeditions on the Ruwenzori, and resulted in the work of Menzies, Bergström, Heinzelin, etc. In addition, the Uganda Surveys Department was able to make the first large-scale maps of the Ruwenzori (Margherita, sheet 65/r I, I :50,000, Directorate of Overseas Surveys, ist edition, 1957; Central Ruwenzori, sheet 326, I :25,00o, Directorate of Overseas Surveys, ist edition, I960).

\section{The Pattern of Ice Distribution}

By comparison with glaciers of high latitudes, the 37 existing Ruwenzori glaciers are small in extent, the largest (the Vittorio Emanuele Glacier) being no more than $476,577 \mathrm{~m} .^{2 *}$ in area. The total Ruwenzori ice coverage is slightly less than $5 \mathrm{~km}^{2}{ }^{*}{ }^{*}$ of which the ice on Mounts Stanley and Speke accounts for over three-quarters. The general distribution of the ice is shown in Figure $\mathrm{I}$.

\section{The glaciers of Mount Stanley}

In addition to possessing the greatest number of summits over $4,878 \mathrm{~m}$. Mount Stanley also claims the greatest area of ice of all the Ruwenzori mountains. From the Alexandra Glacier in the north to the Savoia Glacier in the south, the ice cover extends slightly over $3 \cdot 2 \mathrm{~km}$., while from west to east the glaciers cover almost $\mathrm{I} \cdot 6 \mathrm{~km}$. in width. The approximate area of the ice cover is $2 \mathrm{~km} .^{2}$.

It has been suggested that beneath the ice cover Mount Stanley may be formed by a plateau at an elevation of about 4,573 m., above which stand the high summits. It seems possible that the latter are ancient monadnocks rising from an uplifted peneplain (personal communication from E. J. Wayland quoted by Willis (1936)) but, whatever the origin of the plateau surface, it is manifest that it has served as an important gathering ground for ice formation, so that the Mount Stanley ice plateau is the most extensive ice cap of the Ruwenzori. It serves as a direct feeder to the Margherita, East Stanley, Elena, West Elena, Moebius, West Stanley and Alexandra Glaciers. There are five self-contained glaciers, four of them at the southern end of the mountain-the Savoia, Coronation, and two, hitherto unnamed

* These figures are approximate, being based largely on aerial photographic evidence. 


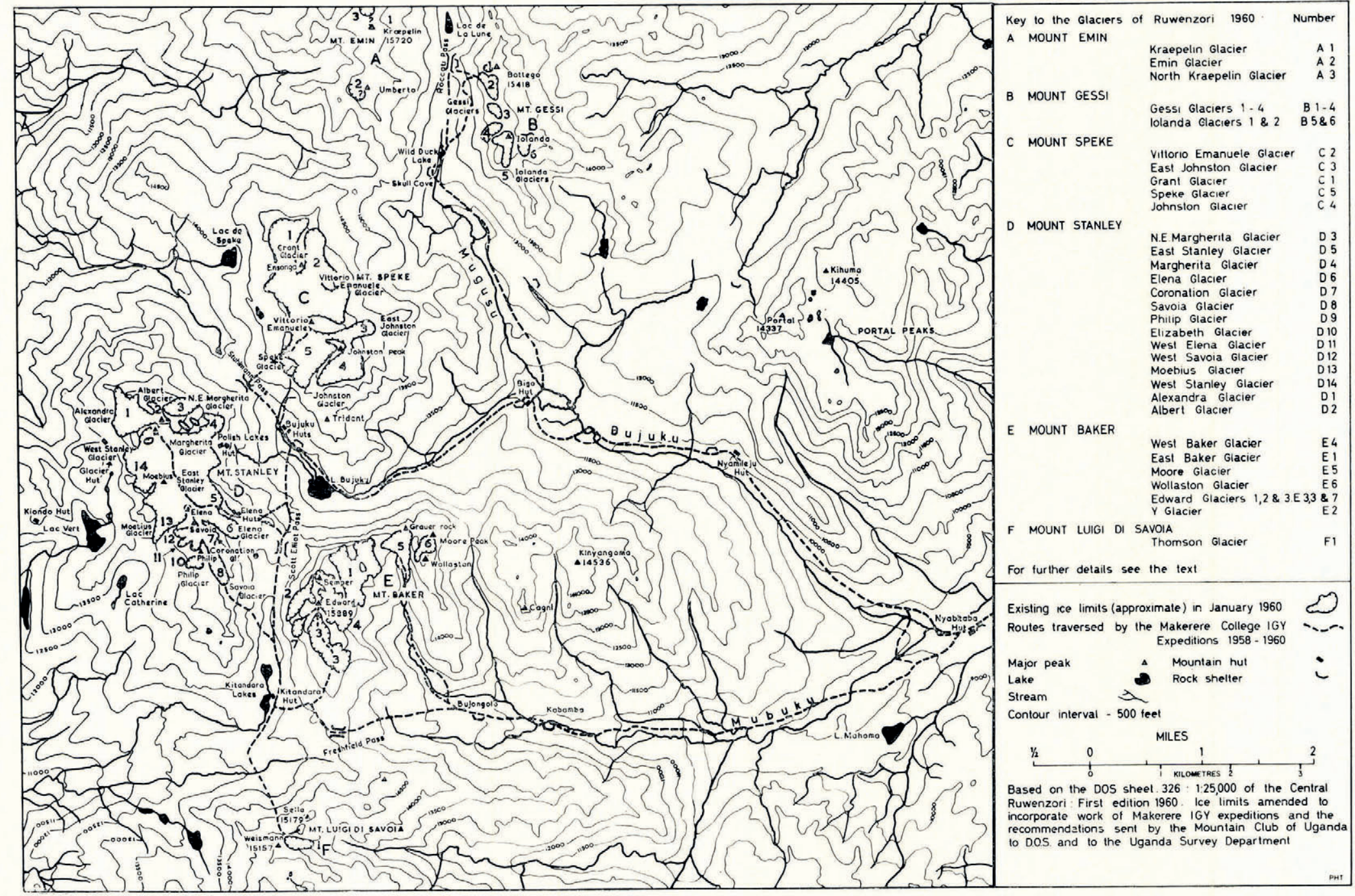

https://doi.org/10.3189/S0022143000028124 Published Fig. I. Central Ruwenzori. Approximate ice distribution in 1960 with the routes followed by the Makerere College expeditions 
glaciers, for which the names Elizabeth and Philip Glaciers have now been given; and at the northern end a small cirque glacier north-east of Margherita Peak, which is now called the North-east Margherita Glacier.

The Elena Glacier, first examined in 1906 by the Duke of the Abruzzi, has been studied in some detail by several expeditions and is described in more detail below.

The Margherita Glacier is the broad ice tongue which descends from the col between Alexandra and Margherita Peaks towards the Bujuku valley. The steepness of the gradient has resulted in extensive crevasse and serac formation. A large section of the snout is about to be isolated from the main glacier, and will no doubt stagnate rapidly in its own small basin which lies at an elevation of only 4,573 m., approximately at the firn line. So far as is known, no glaciological work has been carried out on this glacier, although the new climbing hut at Polish Lakes, near the glacier terminus, should facilitate future work.

The North-east Margherita Glacier, a small hanging glacier directly beneath the highest peak, is by no means easily accessible.

Between Margherita and Albert Peaks an ice mass, which overhangs the north-eastern side of the summit ridge, appears to have been named the Albert Glacier.

The extensive Alexandra Glacier, which descends in a series of steps westwards from the highest summits, is on the Congo side of the Ruwenzori. Although it has been photographed repeatedly, it has not been studied in detail. The converse is true of the West Stanley Glacier, which has been visited by several Belgian expeditions. This work is adequately described by Heinzelin (1955).

The Moebius Glacier, a narrow, steep and heavily crevassed tongue of ice, descends south-westwards from the Mount Stanley ice plateau between Moebius and Elena Peaks towards the valley which contains Lac Catherine (Heinzelin and Mollaret, 1956). So far as is known it has not been investigated.

Although the "Western Elena Glacier" was mentioned in 1932 by Michot ( I933), it is not clear to which of the glaciers he was referring, but it would seem that the name could most appropriately be applied to the glacier descending westwards from between Elena and Savoia Peaks. South of the latter is the West Savoia Glacier which descends from between the Savoia and Elizabeth Peaks, while two small glaciers descending from the Elizabeth and Philip Peaks could, it has been suggested, appropriately bear the names of those peaks.

The Savoia Glacier, a large self-contained glacier covering an area of about $100,332 \mathrm{~m}^{2}$, offers numerous prospects for future glaciological investigation. Several photographs have been taken of this glacier from afar in the past, and more recently work has been done on it by Osmaston ( $196 \mathrm{I}$ ), and Temple and Ball; this is discussed in a later section of this paper.

The Coronation Glacier, a steep, heavily crevassed glacier hanging above the Elena Glacier, is virtually inaccessible from below and can only be crossed in its upper basin. In I 906 it was joined to the Elena Glacier and a photograph taken by Humphreys shows that this was still the case at a later date;* unfortunately it is not certain on which of Humphreys' expeditions the photograph was taken, the earliest possible date being 1926. The two glaciers are now separated by about $60-90 \mathrm{~m}$. of sheer rock slabs.

Finally, there has been some confusion in the past over the position of the East Stanley Glacier, and the name has been used for what is here termed the Margherita Glacier. The eastward-flowing part of the Mount Stanley ice plateau forms a steep ice fall to the north of the ridge bounding the Elena Glacier. A comparison of recent photographs with those of Humphreys shows a marked shrinkage of this ice mass.

Considerable evidence exists, therefore, of the shrinkage of the glaciers on Mount Stanley. Heinzelin has calculated that over $18,394 \mathrm{~m}^{2}$ of ice disappeared from the West Stanley Glacier between 1922 and $195^{2}$. The Margherita and North-east Margherita Glaciers appear

* There is some evidence that in 1943 the Coronation Glacier was still joined to the Elena Glacier. 
to have shrunk markedly in size since r9o6, while the Elena Glacier has also been retreating rapidly, especially in the last decade (Whittow and Shepherd, I958, footnote 16 ).

When it is remembered how conspicuous the Mount Stanley ice plateau and its glaciers are when seen from the upper Bujuku valley, it is somewhat surprising to find that only a very small proportion of the Mount Stanley melt water flows into that valley. The remainder of the water finds its way westwards into the Semliki River via the Lusilubi and Butahu Rivers.

2. The glaciers of Mount Speke

The ice cover on Mount Speke is slightly smaller than that on Mount Stanley, although it includes the two largest glaciers of the Ruwenzori. The ice coverage measures some $2.4 \mathrm{~km}$. from north to south and $\mathrm{I} \cdot 2 \mathrm{~km}$. from east to west, having a total area of about $\mathrm{I} \cdot 62 \mathrm{~km} .{ }^{2}$. Except for the Speke Glacier itself and a glacier to the east of Vittorio Emanuele Peak (now

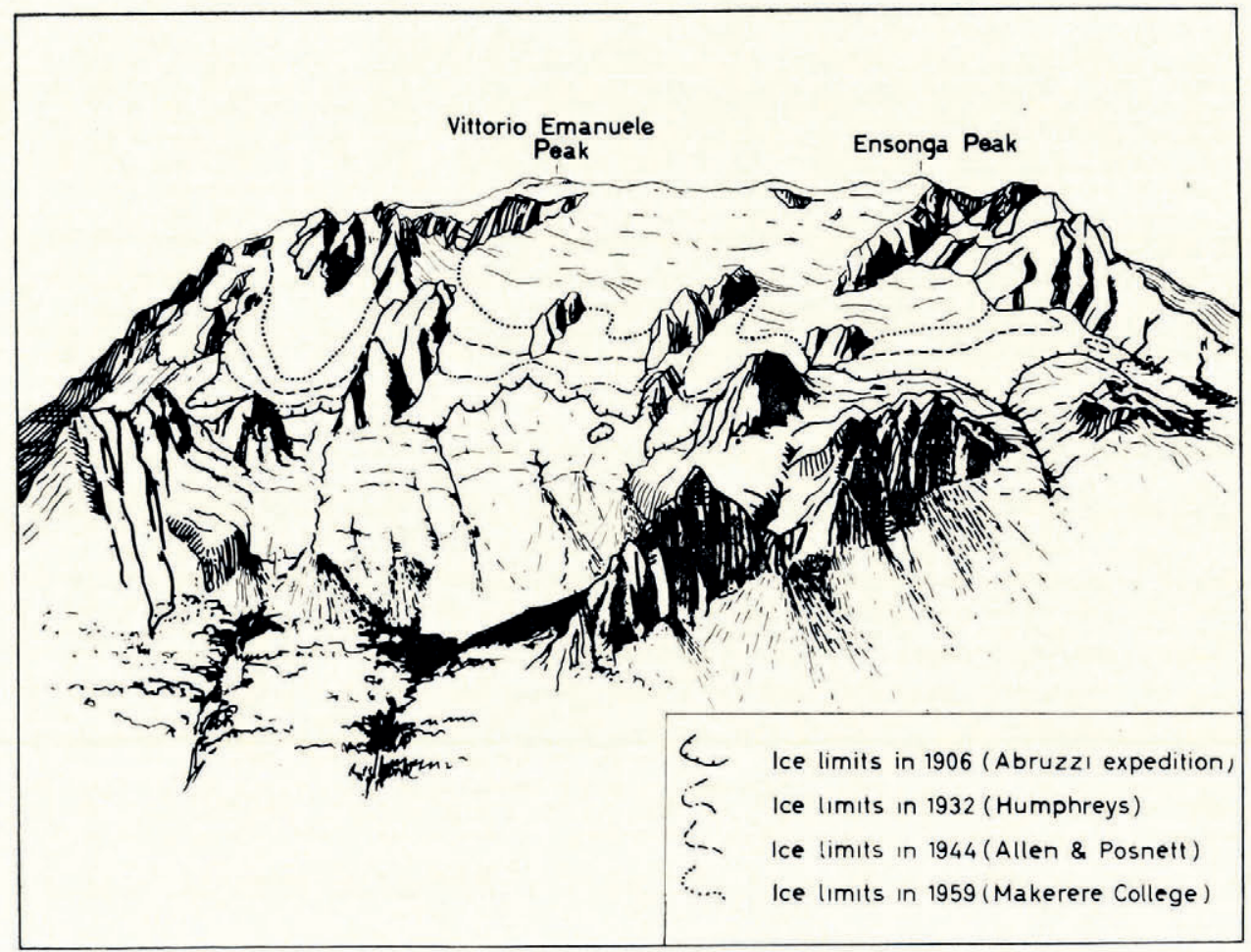

Fig. 2. The eastern glaciers of Mount Speke, 1906-59

named East Johnston Glacier), the glaciers are merely lobes of the summit ice cap. The dearth of well-formed ice tongues, approaching the valley glacier form, is probably caused by the smaller accumulation area along the summit ridge of Mount Speke, as contrasted with the large gathering ground of the Mount Stanley ice plateau.

Thus, the Grant Glacier in the north, and its continuation in the broad ice slopes to the west of Ensonga Peak, can be placed in the latter category (lobes of the ice cap), along with the Johnston Glacier in the south. The eastern slopes of the mountain are largely covered by the biggest of the Ruwenzori glaciers, the Vittorio Emanuele Glacier, which is in fact made up of three main ice streams. The Duke of the Abruzzi included under the title Vittorio Emanuele Glacier the East Johnston Glacier, but it is clear from the Duke's own photograph 
that this glacier was self-contained even in I go6, and it is separated from the Vittorio Emanuele Glacier by a wide rock arête. Photographs of these glaciers were taken, from approximately the same viewpoint on Mount Gessi, by the Duke of the Abruzzi, by Humphreys (probably in 1932) by Hicks, Allen and Posnett in 1945, and by the Makerere College I.G.Y. party in July i959. Four stages of the retreat of these glaciers can therefore be traced and are shown in Figure 2; it seems clear that there has been an acceleration in the recession since 1945 (Hicks, I947) which agrees with the evidence from other Ruwenzori glaciers.

The Speke Glacier has been studied in detail and is described more fully in a later section.

Although it is not possible to give exact figures for the rate at which the ice cover is disappearing from Mount Speke, one isolated example will suffice to illustrate the rapidity of melting in recent years. A small cirque-like depression to the north of the Speke Glacier snout (Fig. 9) was full to overflowing with ice in I9o6, according to the Abruzzi photographs. Successive photographs by Humphreys show it first full of ice and joined to the Speke Glacier, then at a later date, still full but separated from the main ice stream. A map published by the German expedition of $1937-3^{8}$ shows an ice relict of about $16,722 \mathrm{~m} .^{2}$ in area occupying the cirque. By 1955 , this ice had completely disappeared, and it has not re-formed in subsequent years.

About three-quarters of the melt water from Mount Speke finds its way into the Bujuku River, of which it is the principal source.

\section{The glaciers of Mount Baker}

Unlike Mount Stanley and Mount Speke, Mount Baker has no large summit ice cap. The structure of this mountain is such that the steeply dipping rocks have formed a narrow arête-like summit ridge with almost vertical cliffs falling away to the north and west. Thus, most of the ice is found on the less steep slopes, and the glaciers form a south-eastward-facing arc around the head of the Mobuku valley. Owing to the lack of a large accumulation zone, the ice cover on Mount Baker is much smaller than on the two mountains already described; it amounts to approximately $668,880 \mathrm{~m}^{2}$, of which about $460,000 \mathrm{~m} .^{2}$ occur on the southeast-facing slopes and contribute to the run-off of the Mobuku River.

Although the Baker Glacier was the first of the Ruwenzori glaciers to be reached (by J. E. S. Moore in I 90o), no work of glaciological importance has been carried out there. The photograph taken by Moore (albeit somewhat indistinct) and those of the Abruzzi expedition show that the two ice streams which then made up the Baker Glacier were in fact joined, and the 1906 map bears the name accordingly. However, they have since separated, forming two glaciers which are named the West Baker Glacier and East Baker Glacier, respectively. It was noted during the $195^{8}$ visit that the bare rock between the two glaciers was still uncolonized by lichens, therefore suggesting that the division is recent, possibly within the last thirty years (Whittow, I959). It seems quite possible that the East Baker Glacier will again subdivide in the not-far-distant future.

The second largest of the Mount Baker glaciers is the Edward Glacier, which is really no more than a remnant of the summit ice cap. It is accessible without difficulty from the Kitandara hut, but it has not been examined in detail; recent photographs indicate that it may shortly divide into an upper and a lower basin. Immediately to the north of the Edward Glacier are two hanging glaciers, both hitherto unnamed. The smaller of the two seems to have originally formed part of the Edward Glacier system, and this has been named Edward 3 Glacier accordingly (Edward I Glacier and Edward 2 Glacier being the upper and lower basins respectively, as described above). The larger unnamed glacier forms a conspicuous feature on the west face of the mountain as seen from the Elena huts, and it has been photographed frequently, but since it terminates above vertical rock cliffs it appears to be exceptionally difficult of access from below. This has been named Y Glacier after its distinctive shape. 
Above the southern entrance to the Scott-Elliott Pass, the Duke of the Abruzzi's expedition photographed another hanging glacier on the cliffs of Mount Baker which they named the Semper Glacier, and photographs by Humphreys prove that it was still there at least twenty years later. It also appears, though markedly reduced in size, on the 1937-38 German map, and in a photograph taken in 1943 by Firmin (1945). It has since disappeared, but its former extent in 1906 was put at about $62,700 \mathrm{~m} .{ }^{2}$.

In the same way that an individual glacier was studied in detail on Mount Stanley and Mount Speke, a detailed study was made of the Moore Glacier on Mount Baker. Lying at the head of the Mobuku valley, it was one of the best-known glaciers to the early explorers, but it is rarely visited today. A fuller account is given below.

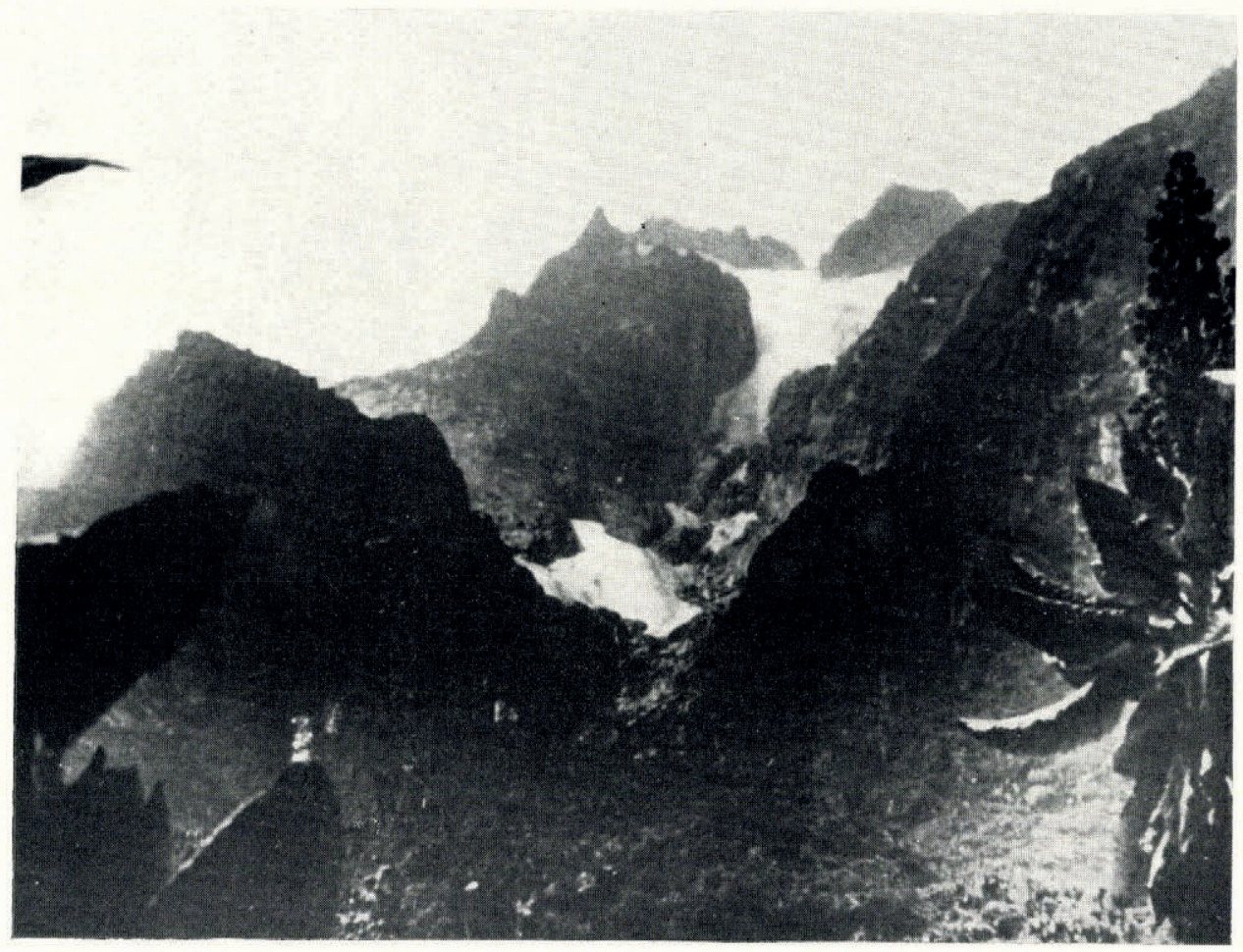

Fig. 3. Iolanda I Glacier, Mount Gessi (July 1959)

Descending from the col between Moore and Wollaston Peaks, a small hanging glacier clings to the cliffs above the Moore Glacier. It was photographed by the Abruzzi expedition and by Humphreys, and it was depicted on the I 937-38 German map; though overlooked on all recent official maps, it is still in existence. It has been named Wollaston Glacier.

Two prominent ice patches on the western slopes of Cagni Peak, which were photographed by the Duke of the Abruzzi in 1906 had disappeared by 1958. They were probably relics of two small hanging glaciers.

\section{The glaciers of Mount Gessi}

The ice cover on Mount Gessi is only about $250,000 \mathrm{~m}^{2}$ and it is dwindling fast. The Duke of the Abruzzi stated that in 1906 "the whole west side of Mount Gessi is taken up by a glacier", which was depicted on his map and named the Gessi Glacier. It seems clear from 
Sella's photograph from Edward Peak of Mount Baker, however, that there were three separate glaciers at that time: a small hanging glacier to the north-west of Bottego Peak, a major central part descending approximately in a north-westerly direction, and a selfcontained glacier which descended southwards to terminate as a narrow snout in a couloir west of Iolanda Peak. Since Igo6 the central part has split into two, and is seen in a photograph taken by Haddow in 1944 (Hicks, 1947). There are accordingly now four glaciers, named Gessi I, Gessi 2, Gessi 3, and Gessi 4 Glaciers, numbering from north to south. The latest aerial photographs show that a similar division has affected the Iolanda Glacier which was originally an ice cap enveloping Iolanda Peak and a second peak to the east. Ice shrinkage has caused a bifurcation leaving a narrow band of pale-coloured rock showing between the two parts. The names Iolanda 1 and Iolanda 2 Glaciers have been given to them, the former being illustrated in Figure 3 .

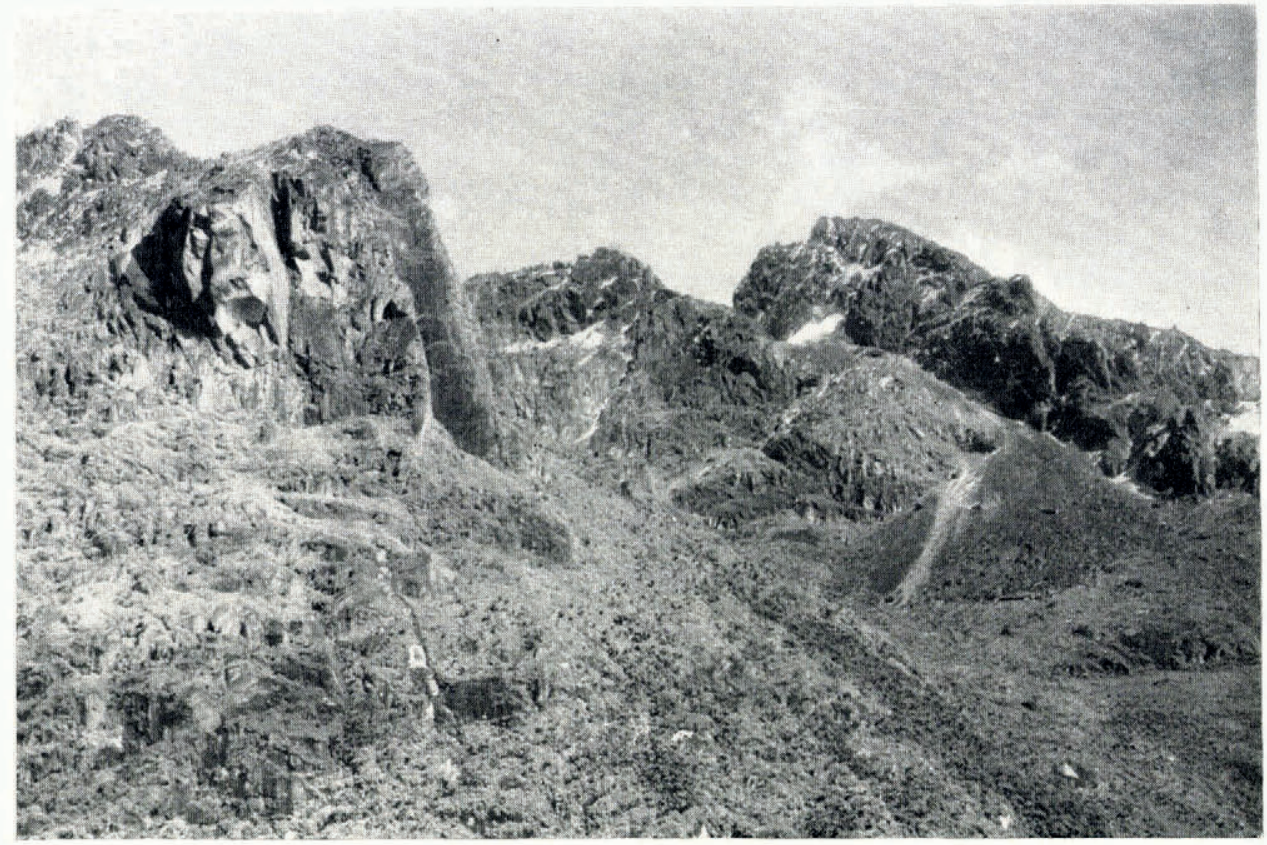

Fig. 4. Mount Emin from the east (July 1959)

Mounts Gessi and Emin have not been visited often, and few descriptive records or photographs of their glaciers are in existence, apart from long-range photographs taken from other Ruwenzori mountains.

Although the run-off from the glaciers of Mount Gessi is not great, almost all of it finds its way into the Mugusu River and hence into the Bujuku River.

5. The glaciers of Mount Emin

The extent of the ice on Mount Emin is not known exactly, but most probably it does not exceed $83,600 \mathrm{~m}^{2}$.

The ice on the east face of the mountain which was first photographed by the Duke of the Abruzzi in 1906, and remnants of which were still in existence in 1945, had all disappeared by I959 (Fig. 4). Part at least of the southward-descending lobe of the Emin Glacier is to be seen in a recent photograph taken by D. Pasteur from a point near the snout of the East Johnston Glacier. It seems probable that part at least of the Kraepelin Glacier is still in existence, for a 
very small portion of it, descending south-westwards from the southern face of Kraepelin Peak, and just visible above the summit ridge, was photographed in 1959. A second glacier, to the north of Kraepelin Peak, can be distinguished on aerial photographs and it has been named North Kraepelin Glacier. For more than one reason, however, it did not prove practicable to approach Mount Emin from the west during the I.G.Y. series of expeditions, and no exploration of the Mount Emin glaciers (as opposed to the peaks) appears ever to have been carried out.

\section{The glaciers of Mount Luigi di Savoia}

Members of the last of the I.G.Y. series of expeditions, in January r96o, ascended the small ice cap of Weismann Peak, but owing to continuous cloud cover they were unable to ascertain the extent of the ice cover on Mount Luigi di Savoia. An estimate gives an area of approximately 33,000 to $42,000 \mathrm{~m}^{2}$, which implies that a great deal of ice has disappeared since igo6. The Stairs Glacier, which formerly descended the northern flanks of Stairs Peak towards the Freshfield Pass, has now completely disappeared, and recent photographs of the mountain from the Freshfield Pass and from the neighbourhood of the Elena huts show that the north face of Mount Luigi di Savoia is quite clear of ice. There are unconfirmed reports by other climbers that the Sella Glacier has also disappeared, but that the relics of the Thomson Glacier can still be seen descending from the ice cap on Weismann Peak eastwards into the Kurugutu valley.

In conclusion it might be said that of the glaciers which were known to have been in existence in 1906 six have definitely disappeared: the Umberto Glacier and two other unnamed glaciers on Mount Emin, the Semper, Sella and Stairs Glaciers, while at least four have split into two or three parts with the appearance, due to melting, of bare rock between the parts. It seems probable that of the smaller glaciers, several, such as the Emin, Gessi 3 , Edward 3, Philip and possibly the North-east Margherita Glaciers, will disappear within the next decade or two. More glaciers may also split, such as the southern ice tongues of the Grant, East Baker and the West Stanley Glaciers. Without a single exception, all the evidence is of a reduction in the ice cover at a rate which has become rapid in recent decades; at no point has the ice cover increased.

As might be expected, the glaciers which are disappearing first are those on the lower peaks at the northern and southern ends of the range. Although the glaciers of Mount Stanley and Mount Speke exhibit abundant evidence of recent recession, it seems unlikely that their summit ice caps will dwindle significantly during the next half-century, even at the present rate of melting. Nevertheless, calculations suggest that the ice tongues descending from these summit ice caps will undergo marked depletion over the next few decades if present trends continue.

\section{Notes on glacier names}

Many of the major glaciers were named following the Duke of the Abruzzi's expedition, while others were named at later dates (for example, the Coronation Glacier, following Busk's ascents) and some on the Congo side received names in Belgian usage. The work of the I.G.Y. expeditions showed, however, that several glaciers were still unnamed, while in other cases what had been a single glacier in 1906 had split into parts which now require separate distinguishing names. A comprehensive review was accordingly undertaken by a sub-committee of the Mountain Club of Uganda (of which one of the present authors was a member), whose recommendations have been officially accepted for use in future maps of the area.

Recent Surveys of the Speke Glacier (Mount Speke)

The Speke Glacier is probably the largest individual glacier of the Ruwenzori. Although the Duke of the Abruzzi was probably the first European to set eyes on it, and although it 
appears on his map, he did not traverse it and in Sella's photographs the snout is obscured by clouds. This is unfortunate, since the character of the snout has changed radically over the past 54 years. The first-published photograph of the glacier appeared after the visit of Humphreys in 1926 (Humphreys, 1927, plate opposite p. 52 I).

Table I. The Glaciers of the Ruwenzori

$$
\text { 1906 } \quad \text { I96o Number on map }
$$

A. Mount Emin

Kraepelin Glacier

Umberto Glacier

Kraepelin Glacier

A

Emin Glacier

Two unnamed glaciers

(disappeared)

Emin Glacier

(disappeared)

$\mathrm{A}_{2}$

The North Kraepelin Glacier is known only from aerial photographs and was presumably in existence in 1906 as well as recently.

B. Mount Gessi

Gessi Glacier

(1906 in three portions)

Iolanda Glacier

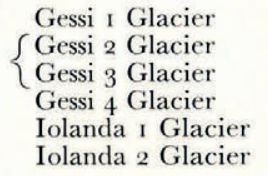

$\mathrm{B}_{\mathrm{I}}$

$\mathrm{B}_{2}$

$\mathrm{B}_{3}$

$\mathrm{B}_{4}$

Iolanda 2 Glacier

B5

C. Mount Speke

Vittorio Emanuele Glacier

Vittorio Emanuele Glacier

(1906 in two portions)

Grant Glacier*

Speke Glacier*

Johnston Glacier

East Johnston Glacier

Grant Glacier

Speke Glacier

Johnston Glacier

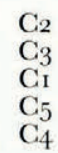

D. Mount Stanley

Margherita Glacier

Stanley Glacier

Elena Glacier

North-east Margherita Glacier $\quad D_{3}$

Margherita Glacier $\quad \mathrm{D}_{4}$

East Stanley Glacier $\quad$ D5

Elena Glacier $\quad$ D6

Coronation Glacier $\quad \mathrm{D}_{7}$

Savoia Glacier

$\begin{array}{ll}\text { Savoia Glacier } & \text { D8 }\end{array}$

Philip Glacier $\quad$ D9

Elizabeth Glacier $\quad$ Dro

West Elena Glacier $\quad D_{1}$ I

West Savoia Glacier $\quad D_{12}$

Moebius Glacier $\quad \mathrm{D}_{13}$

West Stanley Glacier $\quad$ Di4

Alexandra Glacier $\quad D_{I}$

$\begin{array}{ll}\text { Albert Glacier } & \mathrm{D}_{2}\end{array}$

E. Mount Baker

Baker Glacier

Moore Glacier ("Mobuku Glacier")

$\{$ West Baker Glacier

East Baker Glacier

Moore Glacier

Wollaston Glacier

Edward I Glacier

Edward 2 Glacier

Edward 3 Glacier

Y Glacier

(disappeared)

$\mathrm{E}_{4}$
$\mathrm{E}_{1}$
$\mathrm{E}_{5}$
$\mathrm{E}_{6}$
$\mathrm{E}_{3}$
$\mathrm{E}_{3}$
$\mathrm{E}_{7}$
$\mathrm{E}_{2}$

(Unnamed glacier)

Semper Glacier

Thomson Glacier

(disappeared)

(disappeared)

F. Mount Luigi di Savoia

Thomson Glacier

Sella Glacier

Stairs Glacier

* The Grant and Speke Glaciers of 1906 differ in extent from those known by these names today. The ice tongues on the west face of Ensonga Peak were included by the Duke of the Abruzzi in the Speke Glacier; they are, however, continuous with the Grant Glacier. 


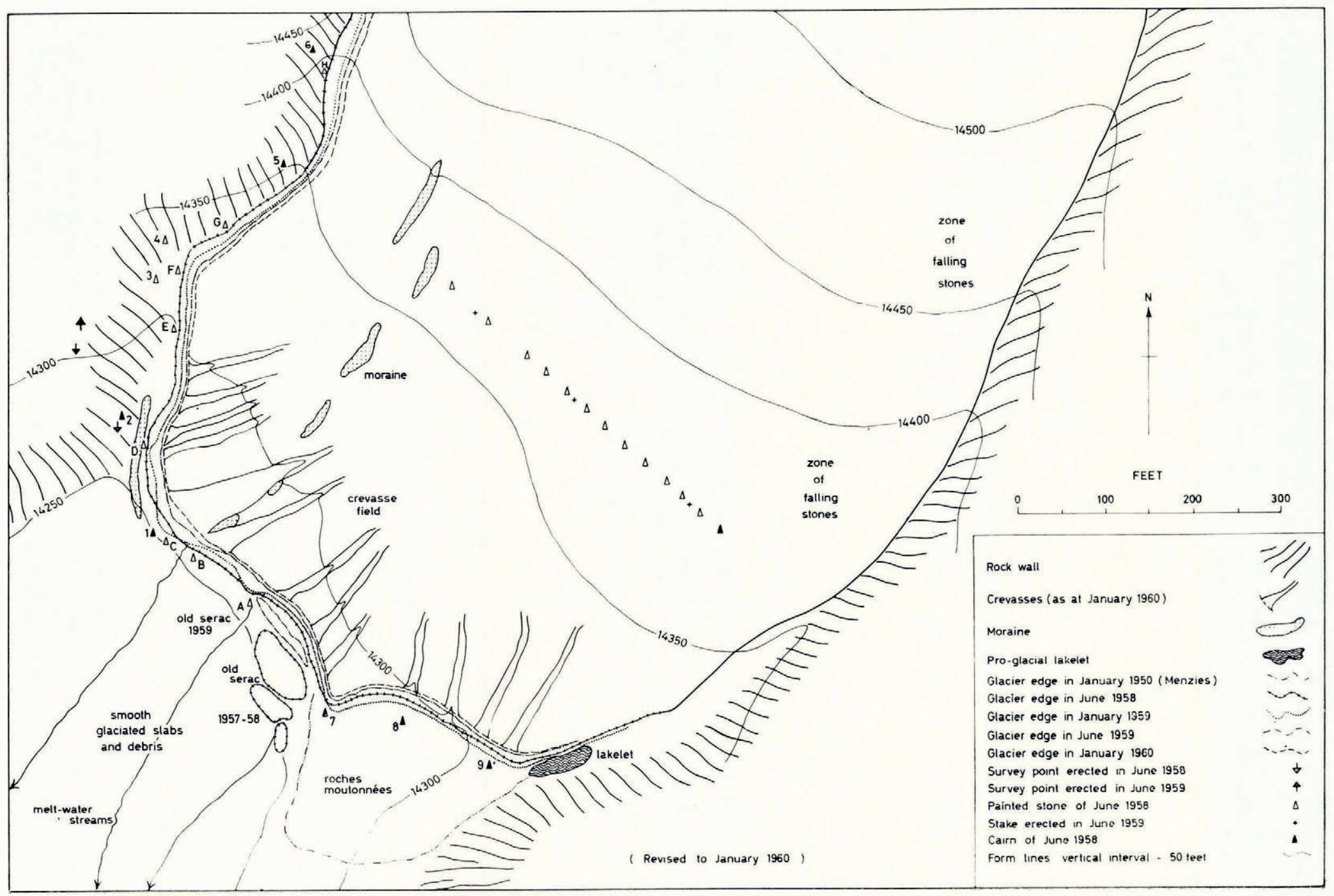

Fig. 5. Snout of the Speke Glacier: recent changes 
It is probable that several photographs of the glacier were taken between 1926 and the visit of Menzies in I $949^{-5}$, but either they have remained unpublished or they are too small to be of great value for comparative purposes. Menzies' visit was significant because the lower part of the glacier was photographed, surveyed and a map was produced at a scale of approximately $1: 2,500$. In $195^{2}$ and again in 1955 aerial photographs of the Ruwenzori were taken (by R.A.F. in April 1952; by Harward Maclachlan (Nairobi) in September 1952; by Hunting Aerosurveys in June and October 1955), and the Speke Glacier was recorded in its entirety at these dates. Between the latter date and the commencement of the Makerere College expeditions, several private parties visiting the Ruwenzori photographed the glacier, and through the kind co-operation of the individuals involved it has been possible to build up a fairly complete picture of the ice changes over the last ten years (Fig. 5).

Members of the Makerere College I.G.Y. Ruwenzori team visited the glacier on every expedition, and the records of the changes are more complete than for any other glacier in this area.

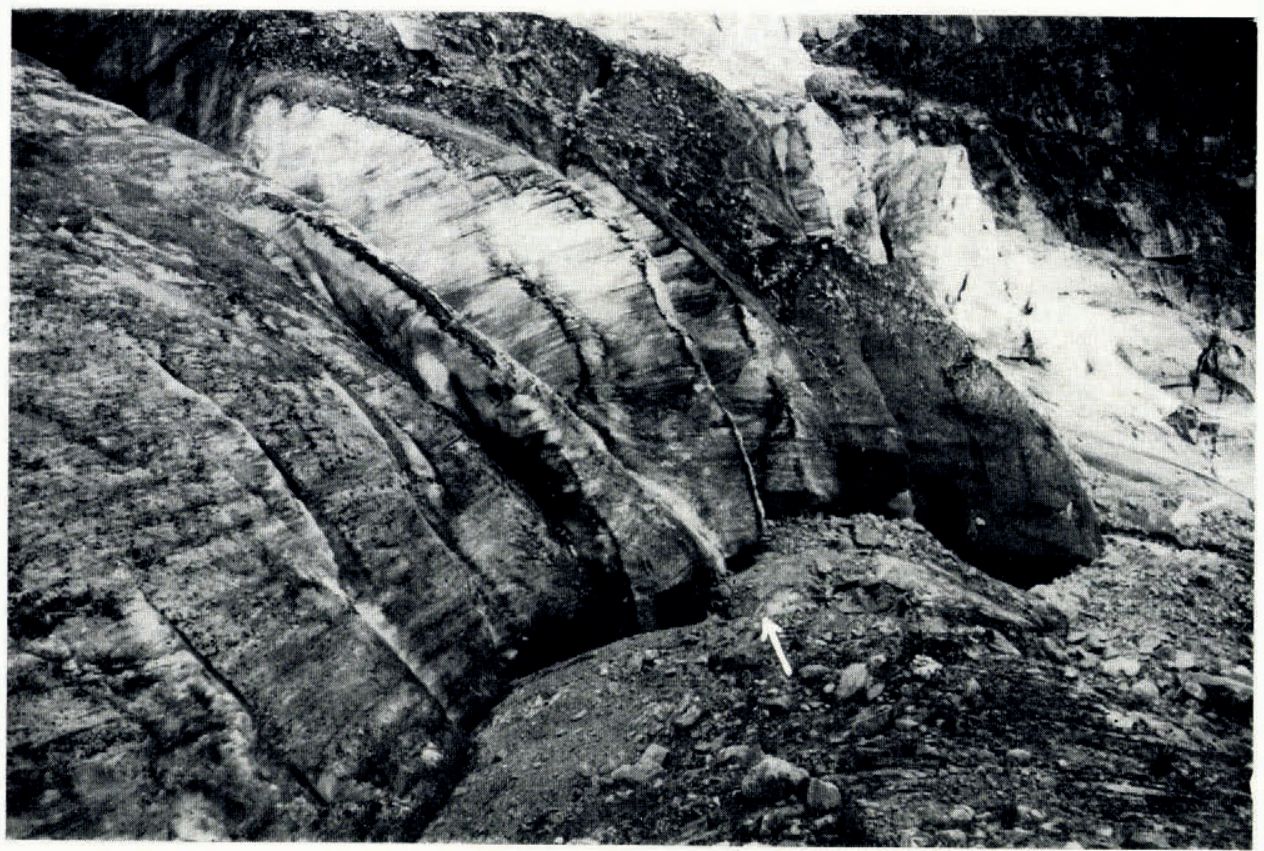

Fig. 6. The snout of the Speke Glacier (June 1.958). Note the painted stones " $C$ " and " $D$ "

The glacier collects its firn from the summit ridge of Mount Speke, and has a total surface area of about $375,000 \mathrm{~m} .{ }^{2}$. The accumulation zone extends from the summit ridge at $4,8 \mathrm{I} 4 \mathrm{~m}$. down to the firn line at about $4,573 \mathrm{~m}$., and is roughly twice the size of the ablation zone $\left(250,000 \mathrm{~m}^{2}\right.$ to $\left.125,000 \mathrm{~m}^{2}\right)$. The glacier descends almost due southwards, curving slightly to the west near its snout, and the present terminus is at about $4,344 \mathrm{~m}$. Three melt streams emerge from the present glacier terminus to plunge over a steep rock wall before cascading over $300 \mathrm{~m}$. down to the Bujuku hut on the valley floor (Fig. 9). The amount of debris and excavation at the foot of the main gully may indicate that at an earlier stage the avalanched ice coming down was sufficient to produce a small regenerated glacier at the foot of the rock wall. The photographs which the Duke of the Abruzzi and Humphreys took of this gully both show a prominent ice or snow cone at its foot, but this had disappeared by the time Menzies visited it in 1949 . 
During most of the visits of the Makerere College party, the surface of the glacier was almost bare of snow up to the firn line, and some prominent patches of medial moraine were revealed. The morainic material ranged in size from large blocks several metres in diameter

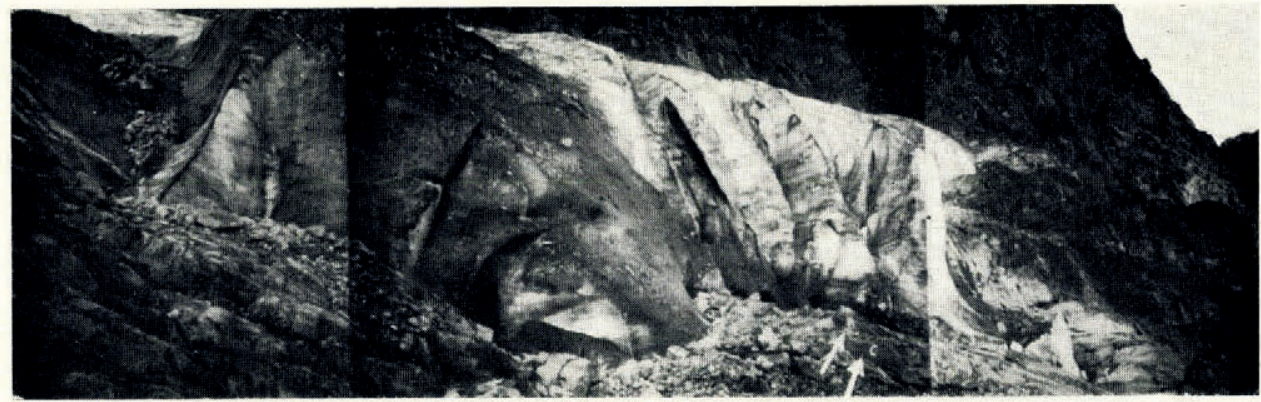

Fig. 7. The snout of the Speke Glacier (7uly 1959). Note the painted stones " $B$ " and " $C$ "

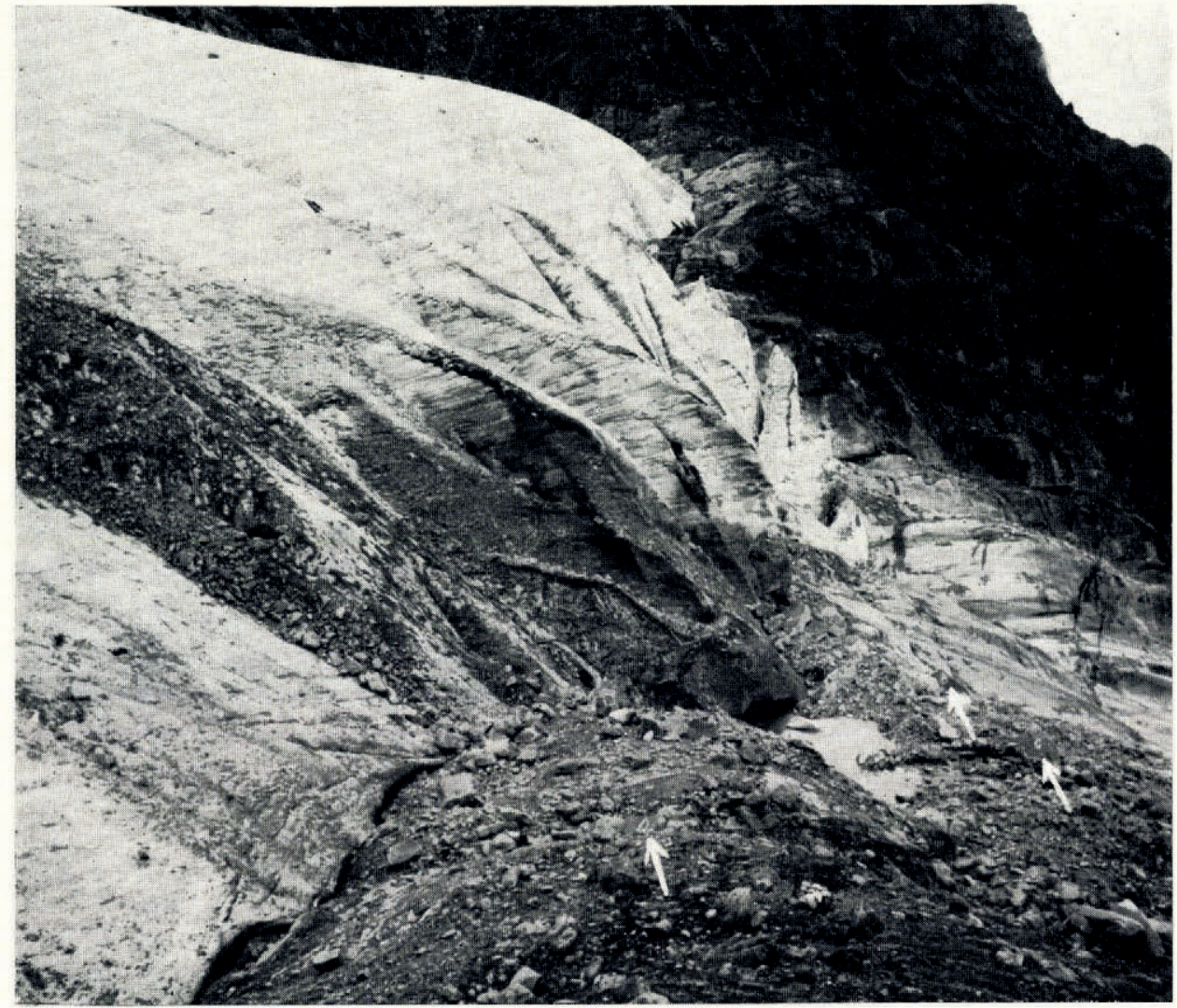

Fig. 8. The snout of the Speke Glacier (July I96I). Note the painted stones " $B$ ", " $C$ " and " $D$ "

to fine rock flour. Some of the larger blocks had formed glacier tables up to I $\mathrm{m}$. in height, and digging showed that these moraines were ice-cored. The source of the moraine could not be traced, but there seems little doubt that it is this surface moraine falling into the terminal 
crevasses which is responsible for the build-up of the small end moraine now forming at the western end of the snout. There is today little subglacial or englacial moraine, a fact noted by Menzies in 1950.

During the i 8 months of study, one large crevasse at the western end of the snout opened out slowly until, by January i96o, it contained a considerable melt-water stream and, higher up, a hole which led through to an ice cave in the heart of the glacier. Small pieces of medial moraine were continually melting out and falling down the hole, presumably right to the bottom of the glacier. During sunny afternoons, which were very rare, the western part of the glacier in the ablation zone was covered with small trickles of melt water.

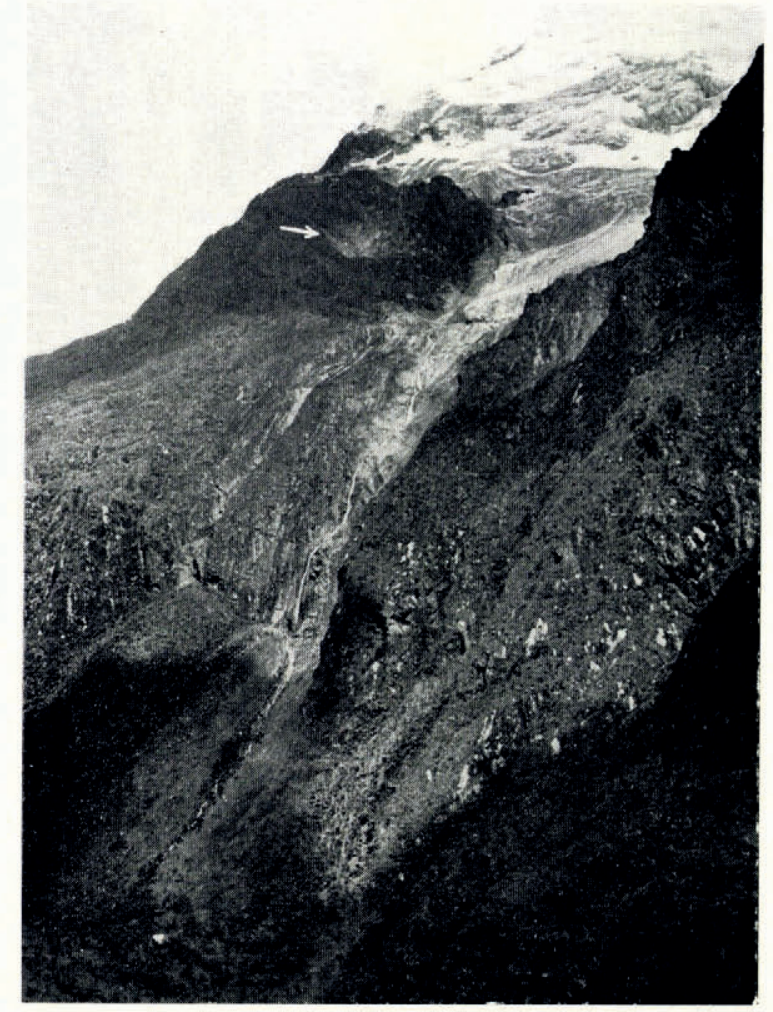

Fig. 9. Mount Speke from the south-west showing the snout of the Speke Glacier and its melt stream, with the Bujuku hut (bottom left) in Fanuary 1958. Note the cirque-like basin, to the left of the glacier snout, which was full of ice in 1906

The glacier is quite heavily crevassed both at the snout and near the firn line, and the terminal crevasses often extend through the total thickness of the ice ( $18 \mathrm{~m}$. at the snout). The pattern of the crevasses changes slowly with the passage of time, while at the snout where the crevasses intersect each other, seracs occasionally break off and fall to the valley floor $300 \mathrm{~m}$. below. In three years at least three separate groups of seracs have broken off and have either fallen or melted in situ (Figs. 6, 7 and 8). Although their collapse appears to have been the result of slight forward movement of the eastern half of the glacier snout, they may also have been undermined by melt water. Spink (I949) contends that the absence of seracs in the glaciers of Mount Kenya and Kilimanjaro results from the special nature of the ice, possibly caused by the extreme fluctuations of temperature in low latitudes. The presence of the Ruwenzori seracs may be indicative, therefore, of important contrasts in ice ductility, 
which in turn may reflect significant differences in the climatic environments of the Ruwenzori glaciers and those of the other East African ice masses. It has long been realized that, even though the Ruwenzori glaciers show many signs of recent recession, they are undoubtedly better nourished and better preserved than the glaciers of Mount Kenya and Kilimanjaro.

There is no doubt that, in common with all other East African glaciers, the Speke Glacier is in the midst of a recessional phase. The evidence for this is threefold: decrease in length, in width and in thickness. It has not yet been possible to decide the last date at which the Speke Glacier joined the glaciers which formerly descended eastwards from Mount Stanley before flowing together down the upper Bujuku valley, but a series of recessional moraines marking the retreat stages of this trunk glacier are found at intervals between the Nyamuleju hut $(3,292 \mathrm{~m}$.) and Lake Bujuku $(3,963 \mathrm{~m}$.). At a height of $4, \mathrm{I} 43 \mathrm{~m}$. and clearly visible from the Bujuku hut, the most recent recessional moraine lies at the foot of the final rock wall below the present glacier terminus. Although there is a considerable difference in elevation between this last moraine and the present position of the snout, the horizontal distance is only about $450 \mathrm{~m}$; this is comparable to the $550 \mathrm{~m}$. between the snout of the Elena Glacier and its innermost recessional moraine. Since the formation of these moraines, both the Speke and Elena Glaciers have retreated a vertical distance of about $25^{\circ} \mathrm{m}$. up steep rock walls. Therefore, there is some reason to suppose that they are now retreating at about the same rate. It has been suggested by Bergström (1955) that the ice stood at these inner moraines at a date a little later than the Swedish ice advances of 1740 and 1800 .

Measurements taken approximately $150 \mathrm{~m}$. above the snout suggest that the forward movement of the Speke Glacier is very slow and that in places it is almost stagnant. As can be seen from the map (Fig. 5), lines of painted stones and stakes were placed in the ice at various intervals, and these were measured by theodolite from fixed points at each visit. A maximum forward movement of just under $\mathrm{I} \mathrm{m}$. in $\mathrm{I} 8$ months was recorded for two stones at the western end of the line. It was unfortunate that on the last visit, in January ig6o, the glacier was covered with fresh snow and the stones were obscured. The three stakes inserted in June 1959 showed negligible movement by January I96o; the westernmost seemed to have moved furthest. Evidence from the stones is a little questionable because, in the course of time, some have risen above the general level of the surface on small glacier tables and have then fallen off and slid forward. One stone had disappeared completely by June I959. The fact that the westernmost stones have moved slightly more than the others in the line may not, indeed, be due to forward movement of the glacier as a whole but to localized slumping in its bed. The western half of the ablation zone may have already become completely stagnant, a stage that has already been reached by several of the smaller Ruwenzori glaciers, e.g. the Thomson Glacier and the Moore Glacier.

The eastern half of the ablation zone is still relatively active, and that part of the snout below it is the only section of the glacier edge which showed any advance during the 18 months' observation. Between June $195^{8}$ and January 1959, the ice behind cairns 7, 8 and 9 advanced between 0.3 and $0.75 \mathrm{~m}$., but it has since retreated. The crevasse field behind this part of the snout is less extensive than on the western side, and the individual crevasses are smaller in width and length. They do not seem to open out by melting as quickly as those on the western side. The eastern side of the glacier edge does not appear to be retreating from the rock wall as fast as the edge on the western side, and there is less morainic debris. Possible reasons for this are discussed below.

The rate of retreat of the snout itself can be traced from the I926 photograph of Humphreys, the $195^{\circ}$ map of Menzies, and the six-monthly recordings of the Makerere College parties (Figs. 6, 7 and 8). The most spectacular change in the outline of the snout is the total disappearance of the ice tongue which formerly extended down from the eastern side of the glacier terminus. This is shown on Figure 5 as "Glacier edge in 1950 (Menzies)", and photographs show that in 1926 it extended much lower down the rock face. By r950 this 
tongue could not have been very thick, but nevertheless its disappearance between 1950 and I $95^{8}$ does suggest an increasingly rapid rate of retreat over the past 30 years.

The cairns and painted stones marked by the Makerere College expedition in June $195^{8}$ were measured at six-monthly intervals until January 1960 , and then again in July I96r. Some of these markers, especially those on the near-vertical rock walls fringing the ice were accessible only from the glacier itself. Thus, after the shrinkage of the glacier or the collapse of ice-cave roofs, certain of the markers became virtually inaccessible to the expedition members on later visits. This was particularly true of mark $G$ and cairns 5 and 6 , whilst stone A and cairn 7 were buried or swept away by falling seracs. Table II summarizes the retreat of the ice margins over the period of detailed measurements.

Table II. Speke Glacier: Distance from 1958 Painted Markers

Distance (in $\mathrm{m}$.) of ice margin from painted stones (lettered)

\begin{tabular}{|c|c|c|c|c|c|}
\hline Stone & June $195^{8}$ & January 1959 & June 1959 & January 1960 & Fuly 1961 \\
\hline A & $0.9 \mathrm{I}$ & $0.9 \mathrm{I}$ & \multicolumn{3}{|c|}{ Stone buried by collapse of seracs } \\
\hline B & $3 \cdot 9$ & $5 \cdot 9$ & $5 \cdot 9$ & ? & $7 \cdot 7$ \\
\hline $\mathrm{C}$ & $1 \cdot 8$ & $\mathrm{I} \cdot 6$ & $6 \cdot 4$ & $9 \cdot 7$ & $13 \cdot 0$ \\
\hline D & $1 \cdot 37$ & $2 \cdot 2$ & $5 \cdot 0$ & $6 \cdot 7$ & $8 \cdot 4$ \\
\hline $\mathrm{E}$ & In contact & 0.6 & I. 98 & $4 \cdot 6$ & $5 \cdot 6$ \\
\hline $\mathrm{F}$ & In contact & $0 \cdot 9$ & $2 \cdot 9$ & $4 \cdot 3$ & $5 \cdot 6$ \\
\hline G & Vertically below & $3 \cdot 0$ & ? & ? & $10 \cdot 7$ \\
\hline $\mathrm{H}$ & In contact & $3 \cdot 5$ & & Not traceable & \\
\hline
\end{tabular}

Distance (in m.) of ice margin from cairns or rocks (numbered)

$\begin{array}{cc}\begin{array}{c}\text { Cairn } \\ \text { or rock }\end{array} & \text { June } 1958 \\ \text { I } & 9 \cdot 1 \\ 2 & 9 \cdot 1 \\ 3 & 9 \cdot 1 \\ 4 & 9 \cdot 1 \\ 5 & 8 \cdot 2 \\ 6 & 7 \cdot 3 \\ 7 & 6 \cdot 4 \\ 8 & 11 \cdot 0 \\ 9 & 7 \cdot 3\end{array}$

January 1959
$8 \cdot 2$
10. I
Cairn destroyed
12.5
$8 \cdot 8$
$12 \cdot 7$
$6 \cdot 1$
$10 \cdot 9$
$6 \cdot 9$

June 1959
$\mathrm{I} 3 \cdot \mathrm{I}$
$\mathrm{I} 1 \cdot \mathrm{I}$

$\mathrm{I} 3 \cdot 4$
$\mathrm{1} 3 \cdot 7$
$9 \cdot 4$
$13 \cdot 6$
$7 \cdot 4$

$\begin{array}{cc}\text { January } 1960 & \text { Fuly } 196 \mathrm{I} \\ 15.5 & \mathrm{I} 7.0 \\ \mathrm{I} 2.5 & \mathrm{I} 3.5 \\ \text { No subsequent measurements } & \\ 13.4 & 17.4 \\ \text { Cairn inaccessible } & ? \\ 14.6 & \text { Cairn buried } \\ 7.9 & 13.1 \\ 10.4 & 15.1\end{array}$

From Table II it can be concluded that the snout is generally retreating along its entire length, despite slight periodic advances at the eastern end. The highest recessional figures are due in part to collapse in addition to normal ablation.

The glacier is also decreasing in width (Figs. Io and I I). Comparison between the I950 and 1960 maps shows a reduction in width just above the snout from $292 \mathrm{~m}$. to just under $237 \mathrm{~m}$. This apparently rapid decrease in width in a decade is the continuation of a tendency which has been evident for at least 50 years. Observations by the Makerere College party show a decrease of up to IO. I $\mathrm{m}$. in width in $\mathrm{I} 8$ months.

Other evidence of recent shrinkage is provided by the glacier thickness. A careful examination of photographs taken between 1906 and the present day shows that a considerable amount of rock which was submerged by ice some 30 to 50 years ago is now uncovered. This rock has a light grey appearance in photographs, indicating that there has not been sufficient time for colonization by lichens. In 1950 Menzies estimated the thickness of the ice front at $36.4 \mathrm{~m}$. in places; today it is nowhere more than $\mathrm{I} 8.2 \mathrm{~m}$.

The main reason for the shrinkage of the Speke Glacier appears to be excessive surface ablation caused by direct insolation. There is also evidence of melting due to insolation being reflected and re-radiated from the rock walls near the edges of the snout. This is particularly true on the western side, where several spectacular ice caves are located in positions which make it difficult for melt streams to be entirely responsible for their formation. Temperature measurements near these caves showed that the heat radiated from the nearby rock wall is 
undoubtedly playing an important part in maintaining the present rate of ablation. The supply of fresh firn cannot possibly balance the present ablation rate.

Another factor which affects the degree and location of surface melting is the extent and duration of the shadow cast by Johnston Peak, and the rock wall beneath it, across the glacier surface. The eastern half of the Speke Glacier was seen to remain in shadow until midmorning, by which time clouds had usually obscured the sun. Early morning observations showed that this part of the glacier remained frozen and unchanneled by melt water, and the small marginal lake impounded on the eastern side of the glacier usually remained frozen throughout the day. On the other hand, the western side of the glacier surface received maximum solar radiation for a few hours on each morning when the sky was clear after sunrise. This part of the glacier rapidly developed numerous small surface runnels, some of which helped to enlarge the crevasses near the snout.

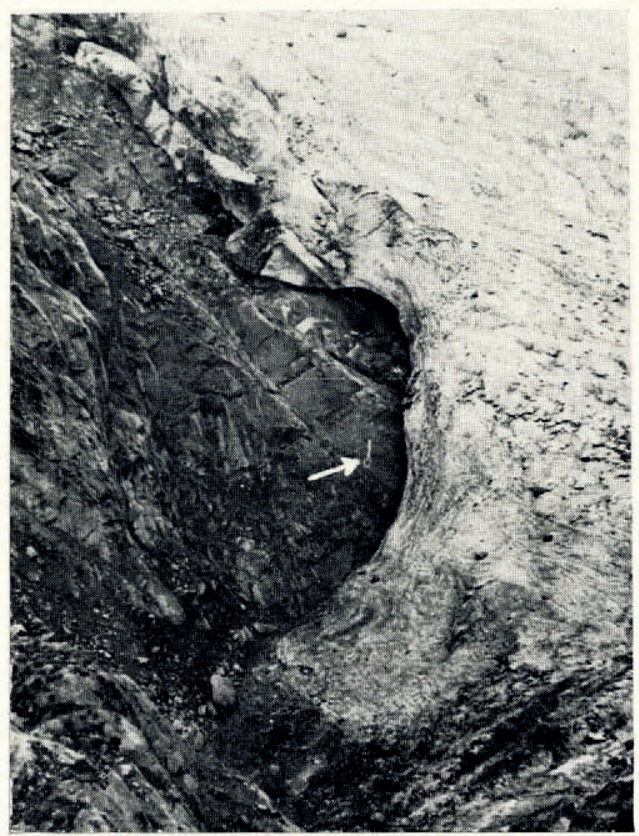

Fig. 1o. Side recession of the Speke Glacier (position in January 1959). Note mark " $G$ ", which was painted vertically below the ice margin in June $195^{8}$

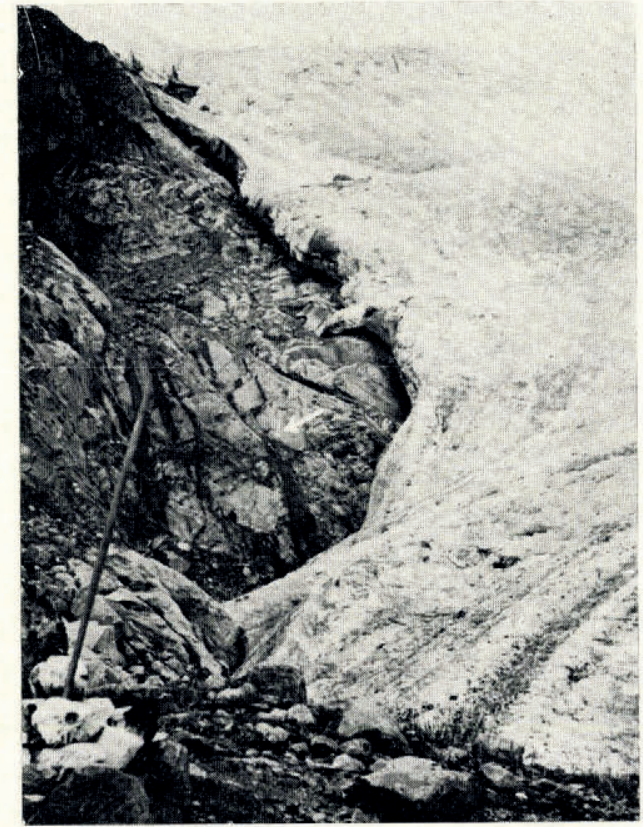

Fig. II. Side recession of the Speke Glacier (position in July I96I). Note mark " $G$ "

The only time of day when the whole ablation zone was likely to be exposed to direct sunlight was in the late afternoon. On several occasions members of the Makerere College party witnessed fitful clearance of the cloud and brief spells of intense insolation at this time of day (Table IV), but these periods were never sufficiently continuous to cause a significant rise in the volume of melt water coming from the eastern side of the glacier. The protection of this side of the glacier by shadow probably played an important part in the preservation for many years of the prominent ice tongue shown on Menzies' map. The slight advance of the snout between June $195^{8}$ and January 1959, and again between June 1959 and January 1960, may also be connected with this factor.

In conclusion it might be said that, if the present ablation rate remains unchanged, the Speke Glacier can be expected virtually to disappear within the next 40 years. It has been calculated that in this time all the ice which occupies the present ablation zone would almost certainly disappear, leaving little but a reduced summit ice cap above 4,573 $\mathrm{m}$. 


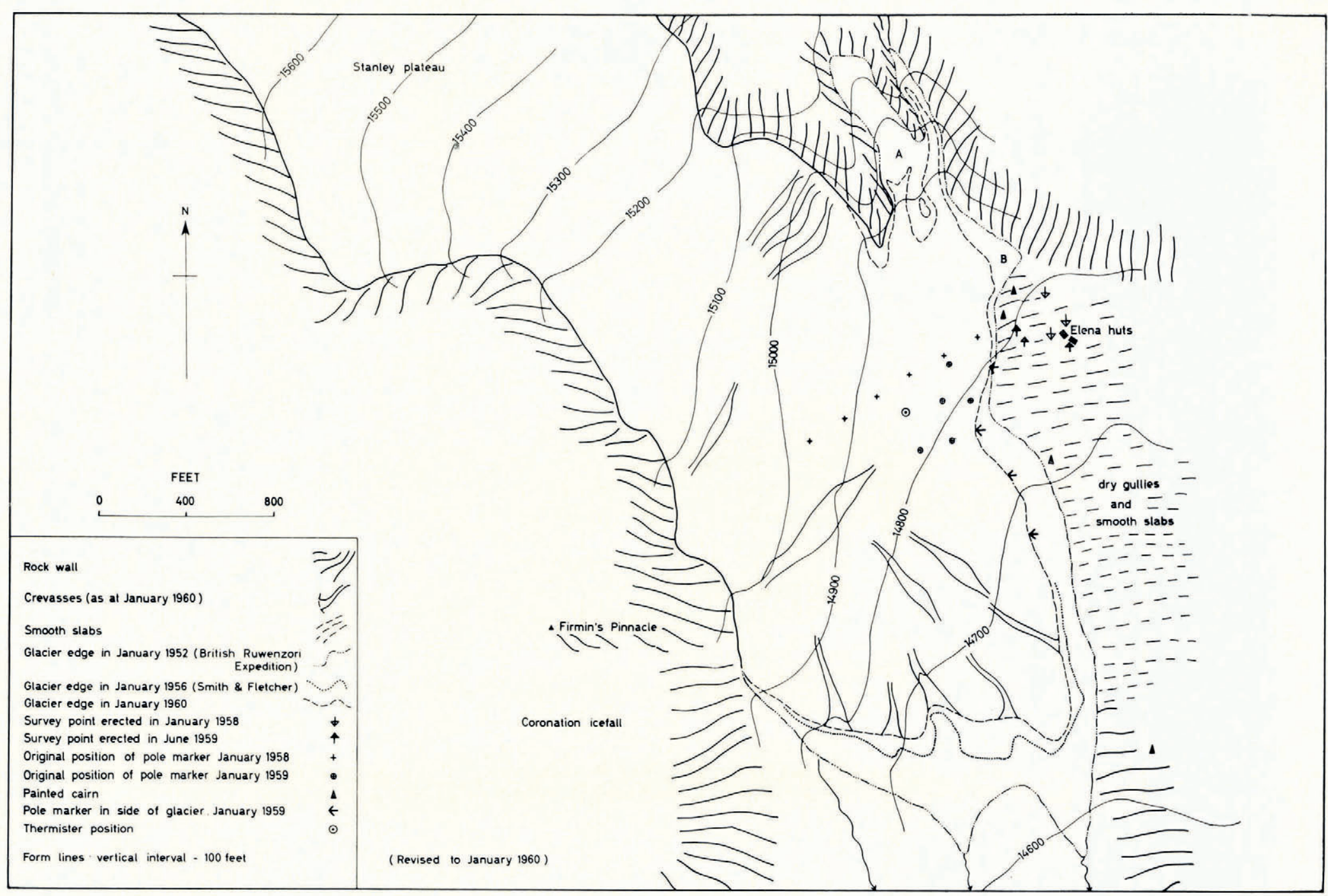

Fig. I2. The Elena Glacier: recent changes 
Regent Surveys of the Elena Glacier (Mount Stanley)

Although the Elena Glacier is not one of the largest glaciers of the Ruwenzori, it possesses one of the longest ablation zones. It is one of six major glaciers which radiate from the central ice plateau on Mount Stanley (Fig. I), and its accessibility has made it an obvious target for glaciological investigation.

The Duke of the Abruzzi was the first person to camp near the glacier. His "ridge camp", however, was established on some relatively sheltered ledges about $90 \mathrm{~m}$. below the site of the present Elena bivouac huts (Fig. I3), at a point which must then have been almost on a level with the snout of the glacier. Photographs of the glacier in Igo6 show the snout hanging down a steep rock wall, up which the ice has since retreated, leaving at least three marked terminal moraines at the bottom. The glacier basin was then much fuller, there being a marked encroachment of the ice into the gullies on the west and north-west side of the glacier

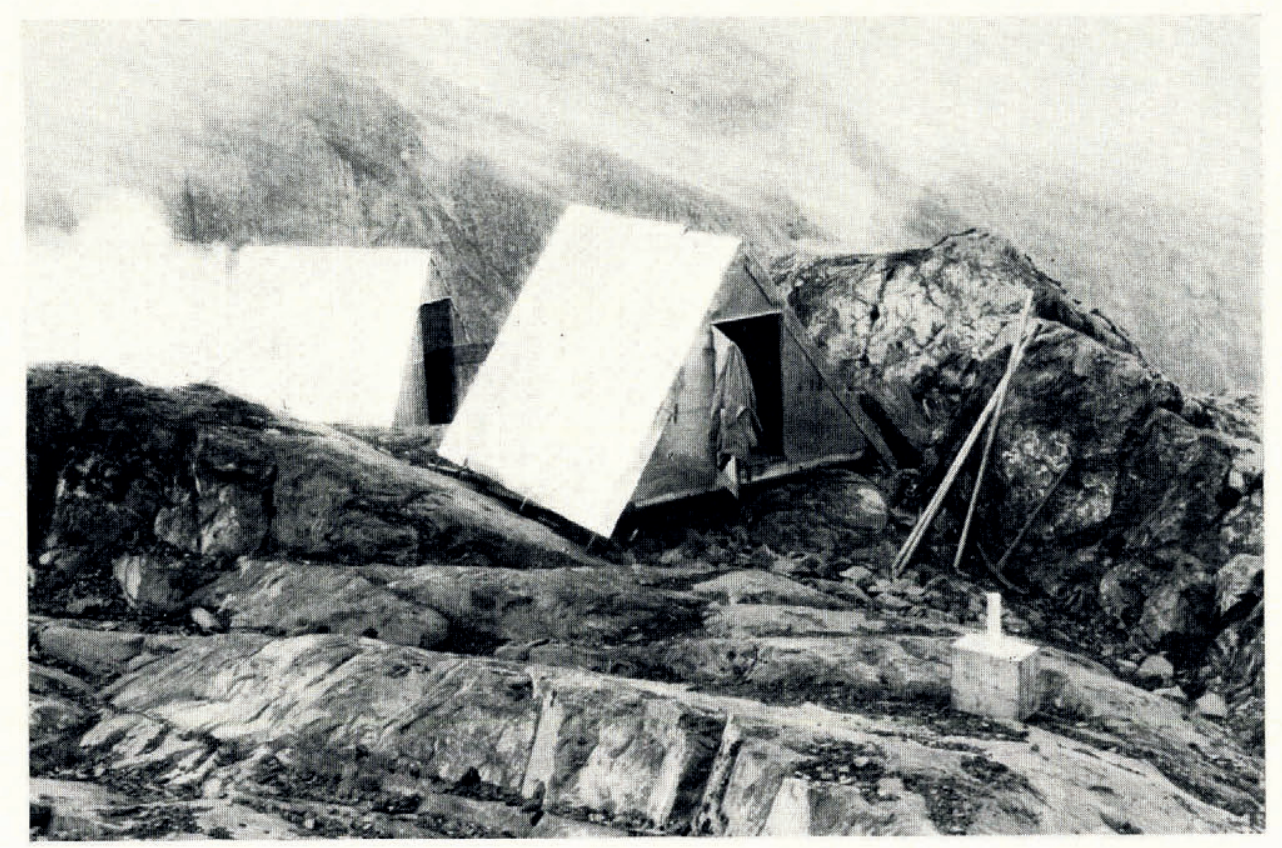

Fig. 13. The Elena bivouac huts. The hut nearest to the camera was built by the Makerere College party in 7 anuary $195^{8}$

and the two prominent gullies (marked " $\mathrm{A}$ " and "B" on Figure 12) were ice-choked to an extent which rendered them unidentifiable individually. A photograph taken by A. H. Firmin in 1943 shows that the Coronation Glacier was confluent with the main Elena Glacier until the mid-1940's (Firmin, I945).

The Elena Glacier was revisited briefly in 1926 and 1927 by Humphreys, whose photographs are of great interest as they show the intermediate state of the glacier between Igo6 and the present day. During his second expedition of July r 926 Humphreys camped for five days near the site of the Abruzzi "ridge camp" and observed that the Abruzzi cairns were already overgrown with lichens (Humphreys, 1927). It was after Humphreys' expeditions that the general retreat of the Ruwenzori ice first became apparent, although no detailed work was undertaken at that time.

The first detailed commentary on the Elena Glacier was published by Menzies (195I[a], [b]) after a visit in December 1949. He calculated that the snout of the glacier stood at 
4,5 I I m., a much higher figure than that for the present day, and much higher than the figure of $4,420 \mathrm{~m}$. given by the British Ruwenzori Expedition of 1952. The present height of the snout is about $4,456 \mathrm{~m}$. and the firn line is just below $4,573 \mathrm{~m}$. Menzies calculated the glacier budget and observed that, in spite of snow falling nearly all the year round, the glacier seemed to have a definite "ablation season" between the middle of June and the end of July, with a less-pronounced one in late December, January and February. The accumulation months are therefore March to May and September to November. The definite ablation season in June and July was confirmed by the Makerere College parties. Menzies also gave the first recession figure for the glacier, based on the assumption that in 1900 , the glacier stood at the last of the moraines at the foot of the rock wall. These moraines were plotted and appear on a small-scale map of the glacier in Menzies' paper. The glacier was surveyed in detail by Menzies and Bergström in $195^{2}$ and a contoured map was drawn at a scale of $\mathrm{I}: 2,000$, showing the ice limits (Bergström, I955). These were revised in $\mathrm{I} 953$ by Osmaston, who visited the glacier on several occasions (Bergström, I955, p. 473). A good idea of the state of the glacier in 1955 is given by photographs of the Coronation Glacier which show four of the survey markers used by the $195^{2}$ British Ruwenzori Expedition still standing in the ice (Busk, 1957, plates 29 and 30 ).

When work was begun on the glacier by the Makerere College parties in January I958, it was found that only one of the 1952 markers remained, and as a result a completely new survey had to be undertaken. Stakes were driven 30 to $50 \mathrm{~cm}$. into the ice in an attempt to measure the rate of glacier flow, but due to either the very rapid surface ablation or the elasticity of the ice, these had mostly become dislodged a mere fortnight after the end of the initial survey. By January 1959, a year later, none of the previous year's markers remained and new ones had to be put in, this time very much deeper. By July 1959 only one of the January markers remained in position. This remaining stake indicated a melt of $75 \mathrm{~cm}$. of ice and $18 \mathrm{~cm}$. of snow in six months. The other stakes had originally been placed in the ice to depths of between 86 and $104 \mathrm{~cm}$. below a variable thickness $(50-70 \mathrm{~cm}$.) of snow. This, therefore, gives some idea of the minimum amount of melting on the glacier surface during the six-month period, although it was not known how rapidly the stakes had become dislodged. It seemed probable that the survival of stakes in an upright position over a six-month period depended more on the depth of the snow cover than on the actual amount of insolation received, for the only surviving stake was standing in $18 \mathrm{~cm}$. of snow in a slight hollow, while those which had been dislodged lay on bare ice on upstanding parts of the glacier surface. Lateral recession and the flow rate of the glacier were measured and the results of this work are summarized below. In addition, three pits were dug in the firn zone and profiles were obtained which have been described elsewhere (Whittow, r960). In January 1960 a deep and extensive cover of fresh snow obscured both the cairns and the ice edge, so that only one of the markers was of use. In July i 96 i the lateral recession was measured and photographs were taken of the snout.

Summarizing as far as possible the recent changes in the ablation zone of the Elena Glacier, the following pattern emerges:

\section{(a) Retreat of the Elena Glacier snout}

I 900 to I920 (Menzies' estimate): I $00 \mathrm{~m}$. or just under $5 \mathrm{~m}$. $/ \mathrm{yr}$.

I 932 to 1952 (Menzies): Ioo m. or just under $5 \mathrm{~m}$. $/ \mathrm{yr}$.

(Osmaston reported an advance of part of the snout of up to $\mathrm{I} \cdot 9 \mathrm{~m}$. between August 1952 and August 1953, but the eastern side of the snout retreated $3.5 \mathrm{~m}$. during the same period.)

I 952 to I960: maximum (eastern snout) $213 \mathrm{~m}$; minimum (centre of snout) $52 \mathrm{~m}$.

A series of photographs illustrating the retreat of the snout between January I959 and July 1961 is shown in Figures I4, I5, I6 and 17 . 
There seems little doubt that, as on the Speke Glacier, a long shallow tongue of ice at the eastern end of the snout has disappeared during the last eight years, and a vertical aerial photograph of 1956 shows the remains of this tongue. The outline of the glacier snout at that time was complex, with seracs and some isolated ice platforms decaying in situ. It must be remembered that the Elena Glacier is inclined at an angle and bearing which traps strong

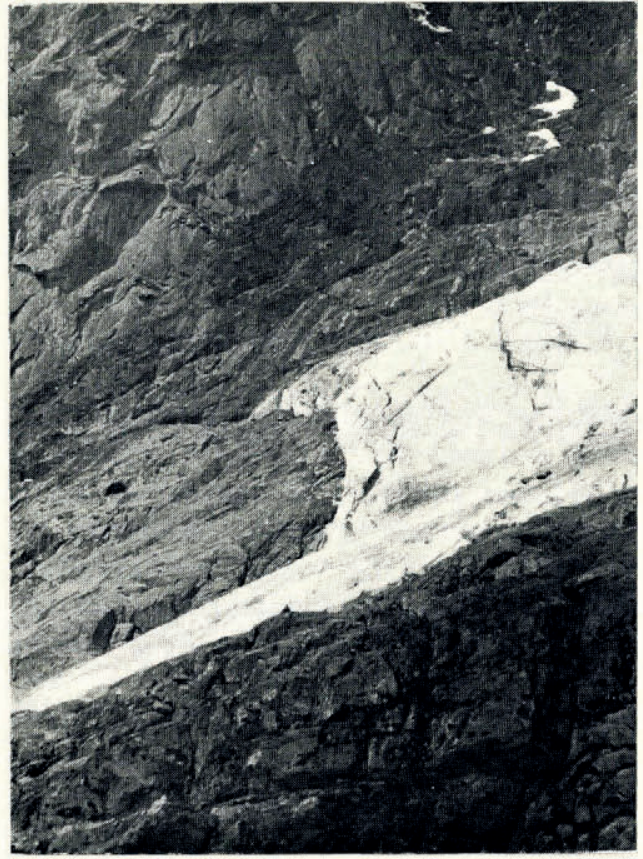

Fig. I4. The snout of the Elena Glacier (January 1959)

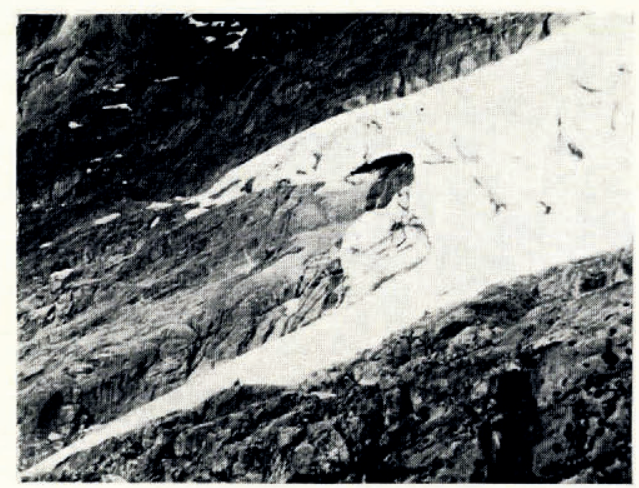

Fig. I6. The snout of the Elena Glacier (January 1960)

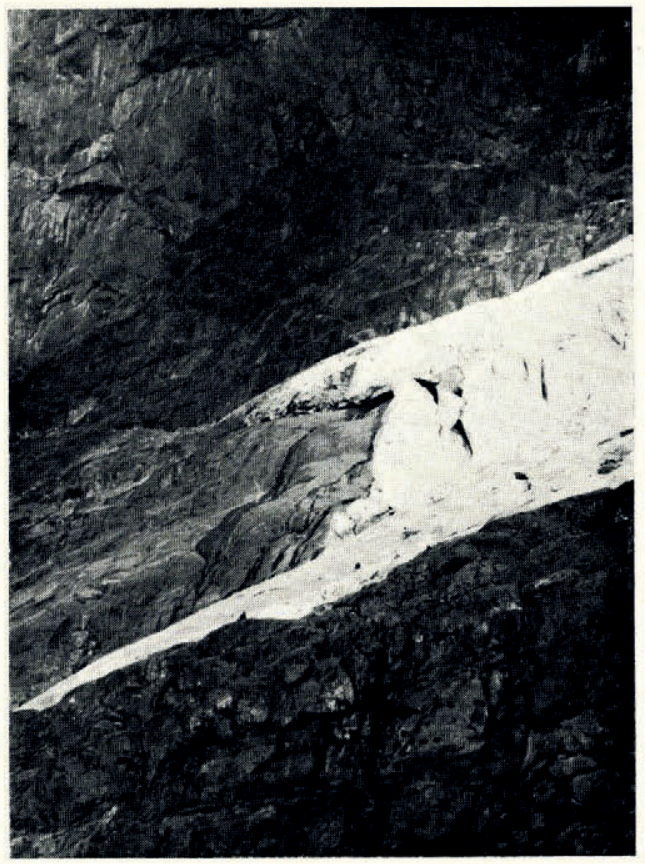

Fig. 15. The snout of the Elena Glacier (Fuly 19.59)

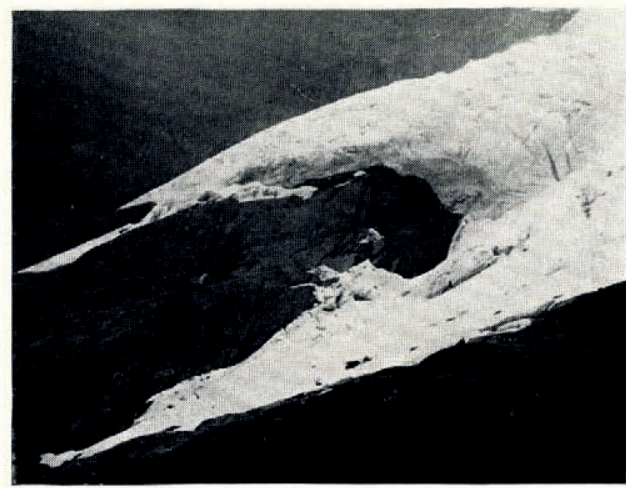

Fig. 17. The snout of the Elena Glacier (Fuly 196I)

insolation from sunrise until late afternoon. This is particularly important in view of the limited hours during which strong insolation is usually experienced in the Ruwenzori. The glacier is also the focus for currents of slightly warmed air which reach over the Scott-Elliott Pass and travel upwards across the ablation zone. 
(b) Lateral recession of the Elena Glacier

I952 to I 960 : maximum $55 \mathrm{~m}$.; minimum $8 \mathrm{~m}$.

\begin{tabular}{ccc} 
& \multicolumn{2}{c}{ Distance of ice from cairn $(\mathrm{m})}$. \\
Cairn & Fanuary 1959 & July 1959 \\
2 & $20 \cdot 1$ & $22 \cdot 0$ \\
3 & $11 \cdot 5$ & $12 \cdot 6$ \\
4 & $8 \cdot 7$ & $10 \cdot 4$ \\
5 & $18 \cdot 7$ & $16 \cdot 1$
\end{tabular}

It must be noted that this six-month period did not include the whole of one of the annual periods of relatively dry weather, and therefore it is not quite indicative of a normal six-month recessional phase.

No measurements of side recession were made on the Pinnacle side of the glacier.

Since the time of the Abruzzi expedition, the width of the glacier just below the bivouac huts has shrunk from about $370 \mathrm{~m}$. to $256 \mathrm{~m}$.

The stakes in the side of the glacier showed melting and sinking of the order of $5.2 \mathrm{~cm}$./ week, with surface melt rates of between 2.6 and $10.4 \mathrm{~cm}$./week. These rates for July 1959 probably represent conditions at the height of the ablation season and should therefore be regarded as maxima.

\section{(c) Surface ablation of the Elena Glacier}

Although it proved impossible in January ig6o to tell the exact amount by which the remaining stakes were still embedded in ice, they were showing between $0 \cdot 94$ and $\mathrm{I} \cdot \mathrm{I} 0 \mathrm{~m}$. above the snow. Assuming that the average snow depth on the ablation zone was between $\mathrm{I} 8$ and $3 \mathrm{I} \mathrm{cm}$. this would give a maximum ablation of $\mathrm{I} \cdot 4 \mathrm{~m}$. and a minimum of $\mathrm{I} \cdot \mathrm{I} \mathrm{m}$. for the period of July I959-January 1960, which accords fairly well with the $\mathrm{I} \cdot \mathrm{o}$ to $0 \cdot 9 \mathrm{~m}$. for the previous six months. The present area of the ablation zone is about $101,500 \mathrm{~m} .{ }^{2}$, but the surface area of the accumulation zone is difficult to estimate, because of its imperceptible gradation into the Mount Stanley ice plateau; a rather arbitrary line appears on the Menzies map.

\section{(d) Forward movement of the Elena Glacier}

Attempts were made in both January and July 1959 to measure forward movements of the glacier at the ice-rock interface by inserting a stake and twice daily comparing the angles made by a fixed theodolite. An average movement of $13 \mathrm{~cm}$./week (with a definite maximum during daylight hours) was indicated, or about $6 \cdot 7 \mathrm{~m}$. $/ \mathrm{yr}$. The one stake in the centre of the ablation zone which proved fairly reliable gave the following figures:

$$
\begin{array}{ll}
\text { January to July i959 } & \mathrm{m} . \\
\text { July I959 to January I96o } & 3 \cdot 7 \\
\text { Total } & 4 \cdot 5 \\
8 \cdot 2 \mathrm{~m} . / \mathrm{yr} .
\end{array}
$$

The present state of the Elena Glacier is therefore one of fair supply and rapid retreat. This is an active glacier, apart from certain stagnant areas on its eastern fringe, but its relatively rapid rate of flow may be due more to its steep angle of slope rather than to its abundance of firn. While it is not possible to record exactly the configuration of the glacier bed, there may be a shallow part at the eastern side and a deep part at the Pinnacle side. Two experiments were made with electronic echo-sounders in an attempt to establish profiles of the glacier bed, but these were unsuccessful. Nevertheless, it seems that the glacier has been retreating from the eastern or shallow part of its bed mainly because this part is out of the direct line of nourishment from the Mount Stanley ice plateau. The snow-filled basin above the Elena huts, which formerly must have supplied some firn to the glacier, is now almost entirely below the firn line itself so that the ice within and immediately below this basin is virtually stagnant. 
Despite the forward movement of the glacier, there are several signs of shrinking within the present bed. The lower part of the ablation zone lies across two broad gullies with a narrow separating ridge, and the glacier is gradually settling into the gullies. Ice caves along the eastern edge and snout of the glacier indicate that the sinking and retreat into these gullies is still continuing, though possibly at a slower rate than during the previous two decades. These caves show change and collapse within short periods of time (Figs. I4-17).

If the calculations of the rate of retreat are not too exaggerated, and if the present rate continues, then the whole of the present ablation zone of the glacier will have melted within the next 35 years.

Work carried out by the Makerere College teams on the Elena Glacier was of a more experimental nature than that carried out on the Speke Glacier. This fact, combined with the premature withdrawal of the second expedition owing to the death of one of its members, meant that the picture of activity of the Elena Glacier over the past three years is neither as complete nor as detailed as that obtained for the Speke Glacier.

\section{The Savoia Glacier (Mount Stanley)}

The Savoia Glacier is the most southerly of the glaciers on Mount Stanley. Its form is simple and the basin in which it lies is self-contained. The glacier is completely separated from Savoia Peak, from which it appears to originate when viewed from the south, by the upper basin of the Coronation Glacier. Its upper limit is, in fact, a smooth snow col east of Philip Peak at a height of a little under $4,878 \mathrm{~m}$. (Busk, I 954). The only recorded observations on the form and regime of the glacier prior to 196 i are those of Osmaston ( $196 \mathrm{I}$ ).

Unlike many of the other glaciers of Mount Stanley, the Savoia Glacier is not merely a tongue descending from the summit ice cap but is a separate entity. The rough dimensions of the ice (quoted by Osmaston) are a length of approximately $609 \mathrm{~m}$. and a width of $152 \mathrm{~m}$. As these are minimum values, this corresponds fairly well to the $195^{8}$ estimate of $100,000 \mathrm{~m} .^{2}$ for the tota! surface area of the glacier. The rate of movement of the ice was measured by Osmaston some way up the glacier between August 1953 and February 1954, and during the six-month period it showed a forward movement of $10.7 \mathrm{~m}$. in the centre of the ice and a forward movement of $4.5 \mathrm{~m}$. at the eastern edge. These figures span a sufficiently long period to give a fair indication of the pattern of movement, particularly as they cover a period of heavy precipitation at the end of the year and a period of strong ablation in January. In June I96I, when the glacier was first visited by a Makerere College party, new snow covered the surface of the ice right down to the snout, but recent photographs of the glacier and observations by Osmaston suggest that the firn line lies between 4,664 and $4,75^{6} \mathrm{~m}$. This is much higher than the neighbouring Elena Glacier but may possibly be explained by periodic incursions of warm Congo air, leading to stronger ablation. Belgian observations suggest that the firn line on the western slopes of the Ruwenzori may be as high as $4,75^{\circ} \mathrm{m}$. The glacier descends from its collecting grounds almost due south to a height of approximately $4,542 \mathrm{~m}$. at its snout (Fig. I8). No detailed survey of the ice has yet been carried out, but a rough map was made of the lower part of the glacier in $196 \mathrm{r}$ and a number of cairns were built round the ice to establish points for more detailed work in the future. Nevertheless, the recent history of the glacier can be pieced together using photographic, morphological and vegetational evidence.

The view of the southern peaks of Mount Stanley and the Savoia Glacier from the top of the Freshfield Pass is a particularly fine one and, as a result, there is a good sequence of photographs of the glacier taken from almost identical positions. Comparison of these photographs is therefore relatively easy and changes in the ice margins can be clearly followed. A summary of the more important stages is shown in Figure I8. The Abruzzi photographs of I 906 are the earliest and they show the basin containing much more ice than at present. The névé field at the head of the glacier appeared to be much thicker and deep snow gullies 
extended towards the summit of Philip Peak. The glacier was also considerably longer, the snout being very regular in outline (except for a small avalanche cone almost detached from the main mass) and probably extended about $250 \mathrm{~m}$. beyond its present edge. This is broadly comparable with the Elena Glacier measurements, if the steeper slopes below the snout of the latter are taken into account. Between 1906 and the present day, there has been a very considerable decrease both in width and thickness of the lower part of the glacier. Humphreys' photographs enable the I927 and I93 I positions to be established, ${ }^{*}$ but the later aerial photographs show a considerable snow cover and are therefore less valuable. Photographs of the glacier in 1934 (Synge, 1937, plates 37 and 38) indicate that only small changes had taken place since Humphreys' I 927 visit, but a marked shrinkage of the glacier is evident from a photograph of Mount Stanley taken in January I943 by Firmin (I945). A broad zone of

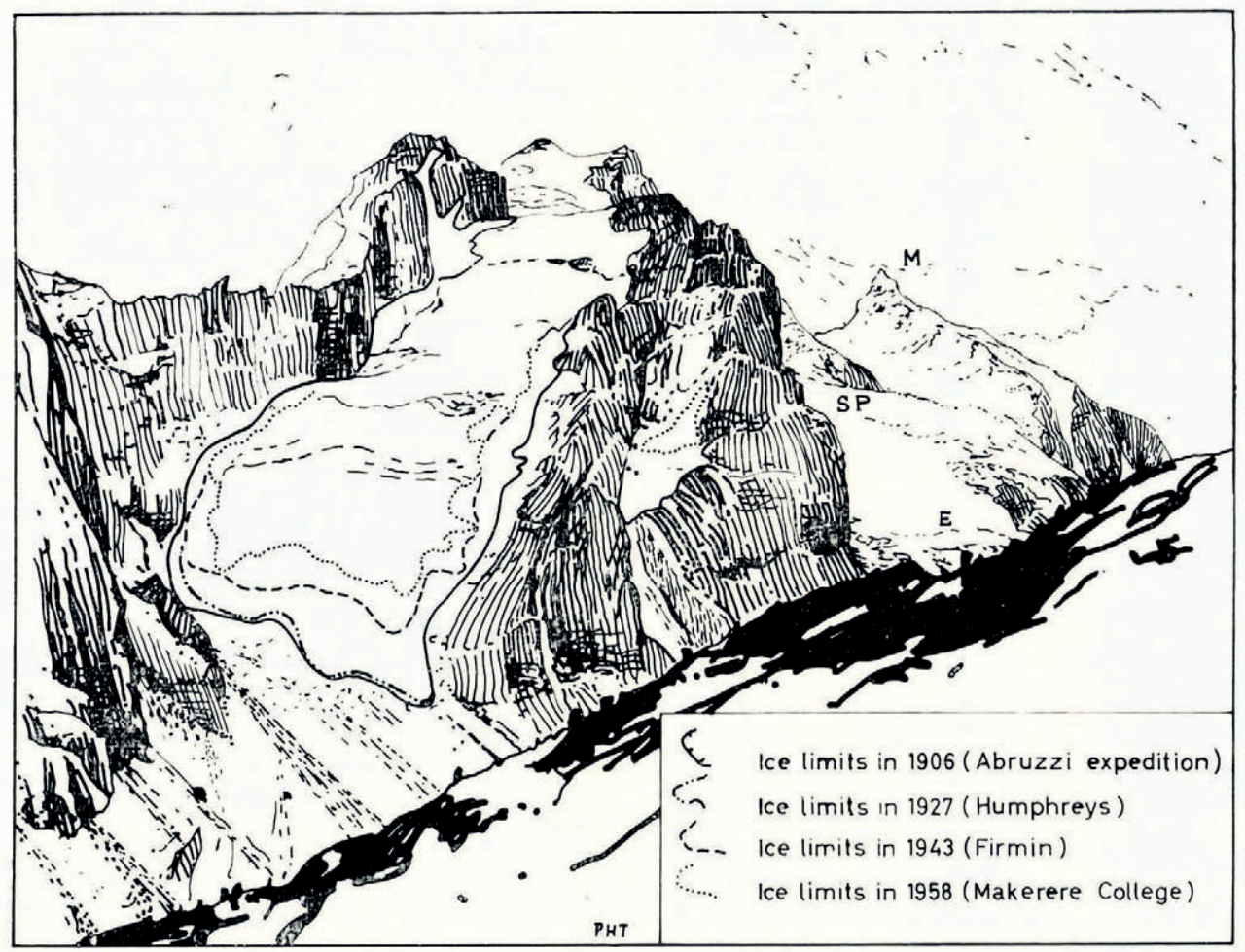

Fig. 18. The Savoia Glacier: retreat stages $(1906-58)$. The upper part of the Elena Glacier $(E)$ can be seen on the right rising up to the Mount Stanley ice plateau (SP) beyond which is Margherita Peak $(M)$

light-coloured newly exposed rock encircles the snout and lower part of the glacier, this being particularly prominent on its eastern side where formerly the snout had extended farthest down the valley. Nevertheless, higher up the eastern side of the glacier, the ice, even in the Duke of the Abruzzi's time, must have been relatively thin, judging by the prominent rocks which showed through it. This zone of thin ice must have melted away completely in the period 1934-43. In addition, the small ice patch lying to the north-east of the main tongue, so prominent in all earlier photographs, had by then been drastically reduced to something closely approximating to its present size. A considerable recession is therefore evident between 1934 and 1943 , followed by a further considerable retreat at the centre of the snout between

* Photographs in the files of the Mountain Club of Uganda. 
I943 and I948.* Photographs taken by a Makerere College party in I958 show further shrinkage in length and width. Between $195^{8}$ and 1961 the changes were relatively slight but the outline of the ice tongue became more uniform through the melting away of two prominent lobes of ice which lay in shallow gullies on either side of the snout. The photographic evidence indicates, therefore, a general retreat since 1906 with an acceleration taking place during and after the middle 1950's. This corresponds to evidence from the other Ruwenzori glaciers which have been studied in some detail.

Lying at a considerable distance below the present termination of the glacier is an extensive well-preserved and fresh moraine. This moraine marks a recessional phase of recent date for it has not yet lost its sharpness of outline nor has it been greatly colonized by vegetation. The Abruzzi photographs show the snout of the glacier just in contact with the fringe of this moraine in 1906, so that it is probably equivalent to the inner moraine of the Elena Glacier (dated as 1900 by Menzies but probably a little older) and the youngest moraine on the Congo slopes of the massif, described by Heinzelin. Below this innermost moraine of the Savoia Glacier, there is a much smaller morainic feature in a gully, but below this the valley slopes steepen and the preservation of a full morainic sequence, similar to that below the Elena Glacier, is missing. Any deposits from ice wastage lower down would not remain in situ but would avalanche to form the extensive screes which are a notable feature of the approach to the glacier from Kitandara.

Immediately below the snout an irregular semi-circular series of vegetation zones can be distinguished. For about $30 \mathrm{~m}$. beyond the ice the ground is almost completely bare; farther from the ice there is a zone of mosses, lichens and scattered tufts of grass. About $90 \mathrm{~m}$. from the snout the first Helichrysum appear together with very small Senecios no more than $15 \mathrm{~cm}$. high. It is several hundred metres farther down-slope before larger Senecios (over $\mathrm{I} \cdot 2 \mathrm{~m}$. in height) appear together with a thick growth of Helichrysum. There would appear to be a distinct correlation between these vegetation zones and the recent recessional pattern of the Savoia Glacier.

\section{The Moore Glacier (Mount Baker)}

There seems little doubt that the Moore Glacier on Mount Baker descends to a lower elevation than any of the other Ruwenzori glaciers. This fact, coupled with its relative accessibility at the head of the Mobuku valley, was responsible for its having been the most frequently visited by the early explorers at the beginning of the present century. It is of interest, perhaps, to note that J. E. S. Moore, the first man to reach the snow line on the Ruwenzori, did not ascend the glacier which now bears his name, as is popularly supposed. It is quite clear from his description and photographs that the glacier he followed to the summit was the Baker Glacier; he mentions that the smaller glacier at the head of the Mobuku valley (now the Moore Glacier) appeared fearfully steep and inaccessible.

Among the early Ruwenzori explorers, Wollaston, the Duke of the Abruzzi, the two Fishers and Sir Harry Johnston, all took photographs of the Moore Glacier which are useful as a means of estimating its recession within the last 50 years. In I 906 Wollaston calculated the elevation of the glacier snout as 4, I 71 m., while the Duke of the Abruzzi (also in I906) thought that it terminated at $4, \mathrm{I} 74 \mathrm{~m}$. The close agreement of these figures leads one to suppose that they are reasonably accurate, and it is therefore unfortunate that during the visit of the Makerere College I.G.Y. party in $195^{8}$ it was not possible to measure accurately the present elevation of the glacier snout. However, an estimate of $4,192 \mathrm{~m}$. is probably not far from the true height of the existing glacier terminus. Although the vertical retreat does not appear to have been very great during the last 50 years, the Moore Glacier has retreated $90 \mathrm{~m}$. since about 1906, judging from the photographs taken by Fisher and Wollaston, with an average recession rate of about $\mathrm{I} \cdot 8 \mathrm{~m}$./yr.

* $194^{8}$ photographs by P. Jenkins in the files of the Mountain Club of Uganda. 
The gradual vegetational recolonization of the rocks below the glacier may enable one to give a more precise dating to the retreat rate of the ice front. For a distance of about $55 \mathrm{~m}$. below the glacier snout the valley floor is free from vegetation of any kind, and the rocks are a characteristic light-grey colour. This zone is probably equivalent to the innermost uncolonized lichen zone noted by Bergström on Mount Stanley in I952. He regarded the outer boundary of this zone as marking the position of the glacier fronts on the Ruwenzori in about I930. If this correlation is accepted, then the Moore Glacier must have retreated approximately $55 \mathrm{~m}$. in 28 years since 1930 , as compared with a retreat of approximately $32 \mathrm{~m}$. in the 24-year period between Abruzzi's I 906 visit and i930. The increased recession rate since i930 adds further support to the evidence of an accelerated deglacierization of the Ruwenzori within the last 50 years.

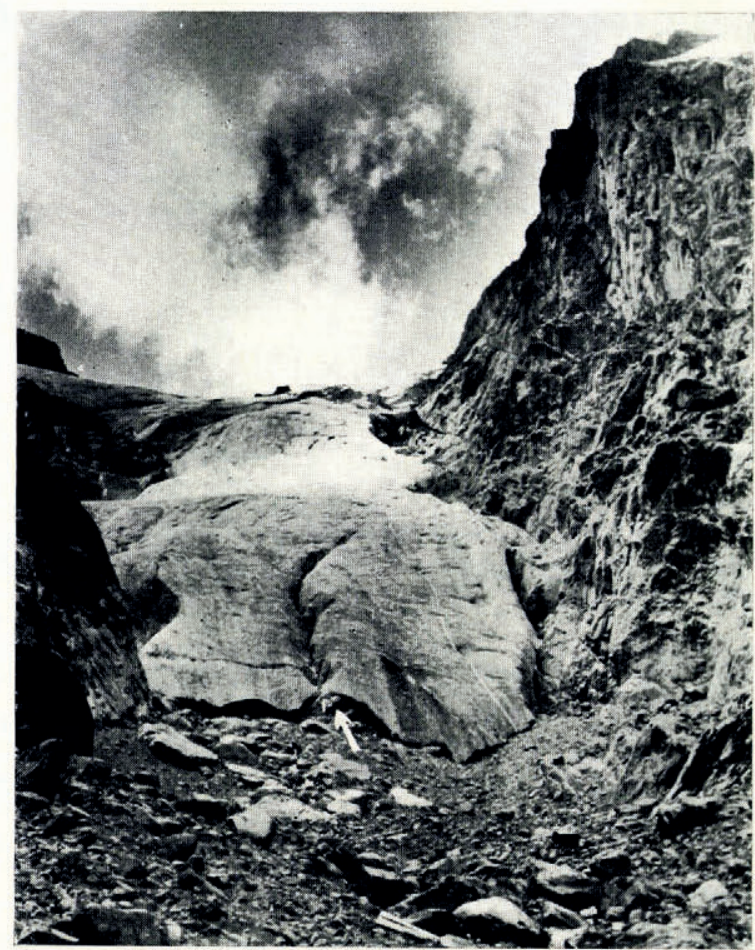

Fig. 19. The Moore Glacier: a dead glacier (June 1958). The rock (arrowed) was painted with a large numeral I. Reproduced by courtesy of the Royal Geographical Society

The recolonization of macroscopic lichens on the valley walls above the existing glacier also testifies to the considerable shrinkage in the ice thickness that has taken place since r 950. Measurements taken in $195^{8}$ slightly above the glacier snout show that lichen growth commences at approximately $3 \mathrm{~m}$. above the present ice surface. On the assumption that the glacier shrinkage has accelerated since 1950, then the glacier snout must have been at least 3-4 m. thicker than at present when visited by the earliest explorers. This fact is borne out by the Fisher photographs which show the snout at least $6 \mathrm{~m}$. thick, whereas in $195^{8}$ it was nothing more than a thin wafer of ice, about $\mathrm{r} \mathrm{m}$. thick, onto which it was possible to walk (Fig. I9). The Wollaston and Johnston photographs depict numerous crevasses and towering seracs at the Moore Glacier terminus, and it was no doubt for this reason that Abruzzi and his guides chose to ascend the steep rock walls to overcome the "terminal fall of seracs". 
An examination of the ice in $195^{8}$ left little doubt that the Moore Glacier is hardly more than a thin tongue of stagnant ice. There are no crevasses or surface moraines which might be indicative of movement and the glacier was seen to be melting at a great rate. The melt streams, which have cut through the ice to become completely subglacial, have carved out wide ice caves. During the 1958 visit a collapse of the existing ice tongue appeared to be quite imminent, so that a retreat of about $9 \mathrm{~m}$. during the 1959 "dry" season would seem to be quite likely.

The location of the Moore Glacier, in a narrow chasm between precipitous rock walls, means that in addition to direct insolation on the ice surface there must be a certain amount of melting caused by the reflected and radiated heat from the rock walls themselves. Evidence of this can be seen at the edges of the ice, where wide gaps separate the glacier from the side walls. The ultimate cause of the rapid recession, however, is probably the gradually increasing elevation of the firn line in the Ruwenzori since the last ice advance, possibly in the mid nineteenth century. At present the firn line on the Uganda slopes of the Ruwenzori stands at an elevation of almost 4,573 m., which means that the upper basin of the Moore Glacier lies entirely below it. Since there is no longer a positive budget, and since the ice thickness has been so greatly diminished during the last $5^{0}$ years, it would appear that if present trends continue the Moore Glacier will cease to exist within the next 20 to 30 years.

\section{Further Scientific Observations}

Numerous other observations of glaciological significance were made at different times during the course of the I957-6r Ruwenzori expeditions. These included measurements of snow accumulation, firn profiles and air-mass movements, which have already been published by Whittow (1960), and detailed meteorological statistics (Makerere College Ruwenzori Expedition, 1959) too lengthy to be included in the present paper. Nevertheless, it is pertinent to note that important relationships exist between these published observations and other glaciological/meteorological measurements, the most significant of which are summarized below.

\section{(a) Temperature measurements in an ice cave under the Elena Glacier (1959)}

The ice cave was located at the eastern side of the Elena Glacier, near the Elena huts. The opening faced due south and its altitude was about $4,55^{8} \mathrm{~m}$., approximately at the firn line.

The mean air temperatures and the maximum and minimum temperatures (Table III) were measured by a normal maximum/minimum thermometer hanging near the wall of the ice cave, but shielded completely from direct insolation. The wet and dry bulb temperatures (Table III) were read from a whirling psychrometer.

In January 1959, when the cave approach was too hazardous for entry, two chains of thermistors were lowered into it via a crevasse. Unfortunately, one of the thermistor chains fell down the crevasse so that the January results were not considered to be accurate enough for inclusion in Table III. By June r959, however, the cave was easily accessible from below and measurements were possible on twelve consecutive days. Since this period was during the middle of the sunniest season of the Ruwenzori year, the temperatures can be regarded as maxima. By January 1960 the roof of the cave had collapsed, so that no further records could be taken.

\section{(b) Melt-water flow rates from the Speke Glacier}

A flow board was erected at a height of approximately 4,024 m. near the Bujuku huts. The stream across which it was placed flowed directly from the snout of the Speke Glacier and contained all the melt-water run-off from the glacier. The flow board consisted of a large plank in which was cut a V-shaped right-angled notch through which the water could flow. 
Table III. Temperatures in Ice Cave of the Elena Glacier, June and July i 959 Maximum and minimum temperatures

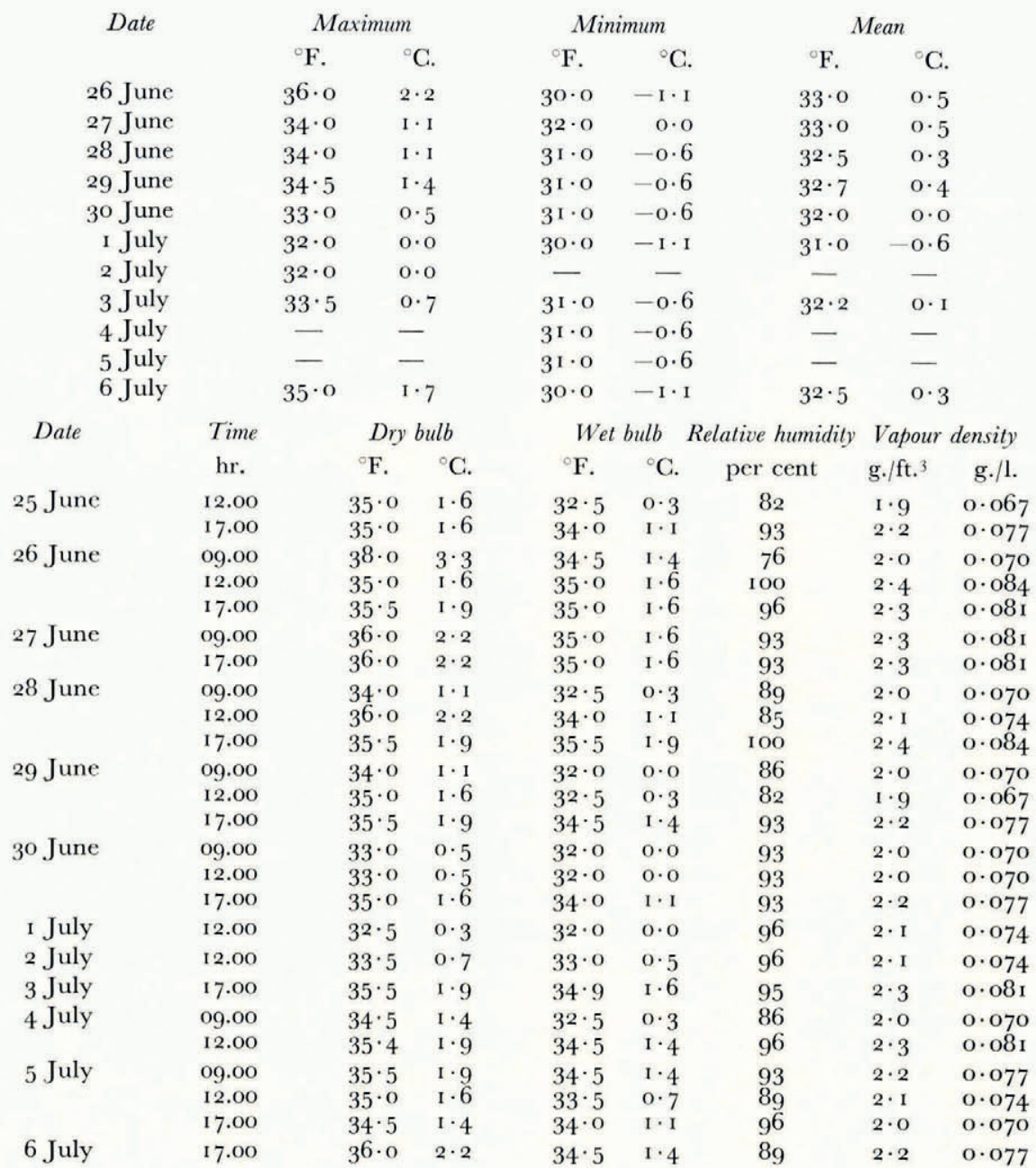

The pool impounded by the flow board was sufficiently large to be regarded as still, and the head of still water in the notch $(H)$ was measured and used to calculate the rate of discharge in $\mathrm{ft} . / \mathrm{sec} .(Q)$. The measured rates of discharge at different times are shown in Figure 20 and were calculated by the formula

$$
Q=0 \cdot 00487 K\left(H-\frac{1}{2}\right)^{2} H^{\frac{1}{2}},
$$

where $H$ is measured in inches. The constant $K$ varies from $\mathrm{I} \cdot \mathrm{o}$ for small values of $H$ to about I. I for the largest values of $H$.

The mean flow rate from 24 June to 5 July 1959 was found to be $0.67 \mathrm{ft}^{3}{ }^{3}\left(\mathrm{o} \cdot 0 \mathrm{r} 9 \mathrm{~m} .{ }^{3}\right) / \mathrm{sec}$., whilst the mean flow rate for 8- I I January i 960 was calculated to be $0 \cdot 80 \mathrm{ft}^{3}\left(0 \cdot 023 \mathrm{~m} .{ }^{3}\right) / \mathrm{sec}$.

In addition to the figures tabulated above recordings were made over shorter periods on three earlier expeditions:

2I-27 June 1958 . Mean flow rate $0.65 \mathrm{ft}^{3}\left(0 \cdot 0 \mathrm{r} 8 \mathrm{m.} .^{3}\right) / \mathrm{sec}$.

IO-I 2 November 1958. Mean flow rate $0 \cdot \mathrm{Io}_{\mathrm{ft} .}{ }^{3}\left(\mathrm{o} \cdot 003 \mathrm{~m} .^{3}\right) / \mathrm{sec}$.

2-5 January 1959. Mean ilow rate $0.25 \mathrm{ft}^{3}\left(0.007 \mathrm{~m} .{ }^{3}\right) / \mathrm{sec}$. 
Values for the melt rate from the glacier, deduced from the flow-board readings, are likely to err on the low side for the following reasons: first, the formula used neglects the velocity of flow into the pool formed by the flow board; secondly, evaporation from the waterfall below the Speke Glacier snout, where much of the water is in the form of fine spray, is neglected; thirdly, any seepage of the water into the stream bed is neglected, but the amount is likely to be small as the channel is composed largely of hard rock.

If the maximum and minimum flow rates for a $24-\mathrm{hr}$. period are calculated, a rough estimate of the mean figure for that period can be found by taking one-third of the sum of the maximum and minimum values. (This empirical formula was deduced from the data for June and July i 959. )

In general the low night value continues during the morning until $12.00 \mathrm{hr}$. when the afternoon rise begins. The maximum is reached at about $\mathrm{i} 6.00 \mathrm{hr}$. after which the flow falls off to its night value of minimal melting. On two occasions the maximum occurred at about I $3.00 \mathrm{hr}$., possibly as a result of a lengthy period of morning insolation on the Speke Glacier

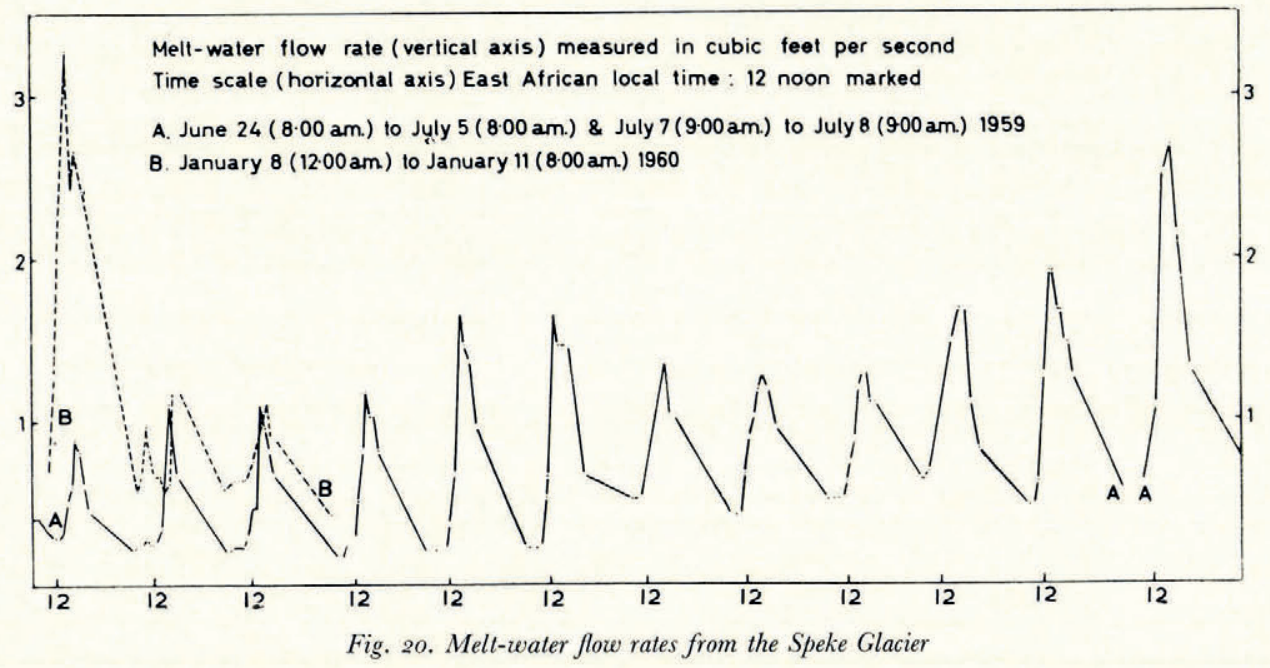

followed by a cloudy and cold afternoon. It is significant that the only flow-rate figures obtained in November during the period of heavy precipitation, which occurs in the Ruwenzori at this time, illustrate that melting and run-off are negligible because of the lower temperatures resulting from reduced insolation.

On an examination of all the existing flow-rate records for the Speke Glacier the mean figure of $0.67 \mathrm{ft}^{3}\left(\mathrm{o} \cdot 019 \mathrm{~m} .^{3}\right) / \mathrm{sec}$. for the June-July r 959 period appears to approach nearest to a "norm" for an ablation season run-off. If this figure is adopted, and the total area of the Speke Glacier is calculated to be 450 , ooo yd. ${ }^{2}\left(376,245 \mathrm{~m}^{2}\right)$, the melt rate for the 12-day period is equivalent to $6 \mathrm{I} \cdot \mathrm{o}$ in. $\left(\mathrm{I}, 55^{\mathrm{O}} \mathrm{mm}\right.$.) of water/yr., or $2 \cdot \mathrm{I}$ in. $(53 \mathrm{~mm}$.) for the period under consideration. Precipitation in June and July 1959 was almost certainly lower than this figure in the vicinity of Mount Speke, so it would seem that on the whole the glacier budget was decidedly negative during that time.

\section{(c) Solar radiation measurements}

Owing to its position almost astride the Equator, the Ruwenzori ice cap offers a unique opportunity to study the effects of equatorial insolation on glacier melting. As might be expected, the intensity of solar radiation can vary greatly over a relatively short time in such a location, and it was therefore thought important to take readings at several stations at or near 
the ice margin in various weather conditions. Such measurements could be used to demonstrate quantitatively that important correlations exist between glacier melt-water flow rates and the intensity of solar radiation.

At all the stations (Table IV) the following method was adopted in June and July r959: a square white matt screen was placed horizontally on or near the ground. Its brightness was measured in terms of the reading on a Weston Master Mark II exposure meter held vertically I ft. $(0.3 \mathrm{~m}$.) above the screen, in such a way that no shadow was cast. The operation was repeated with a black matt screen and the difference between the two readings was tabulated. In very bright sunshine the Weston meter reading exceeded full scale and a stop was therefore constructed to reduce its sensitivity to half.

The apparatus was calibrated in the laboratory with a standard 2,320 candela lamp placed vertically above the screen. The Weston meter reading is very nearly proportional to the illumination of the screen, and one unit Weston meter reading corresponds to an illumination of 12 lumens/ft. ${ }^{2}$ ( 129 lux).

In January i 960 solar radiation readings at the Bujuku hut were taken with a black bulb thermometer in vacuo. It is difficult to establish a correlation between readings taken with the black bulb thermometer and those obtained with the Weston Master exposure meter. In direct sunlight, about noon, the exposure meter technique gave the value I,930 Weston meter units, whereas the black bulb thermometer read $120^{\circ} \mathrm{F}$. $\left(49^{\circ} \mathrm{C}\right.$.) when the dry bulb in screen temperature was $59^{\circ} \mathrm{F}$. ( $15^{\circ} \mathrm{C}$.).

Table IV contains a selected number of the solar radiation measurements recorded in I959.

Table IV. Solar Radiation Measurements

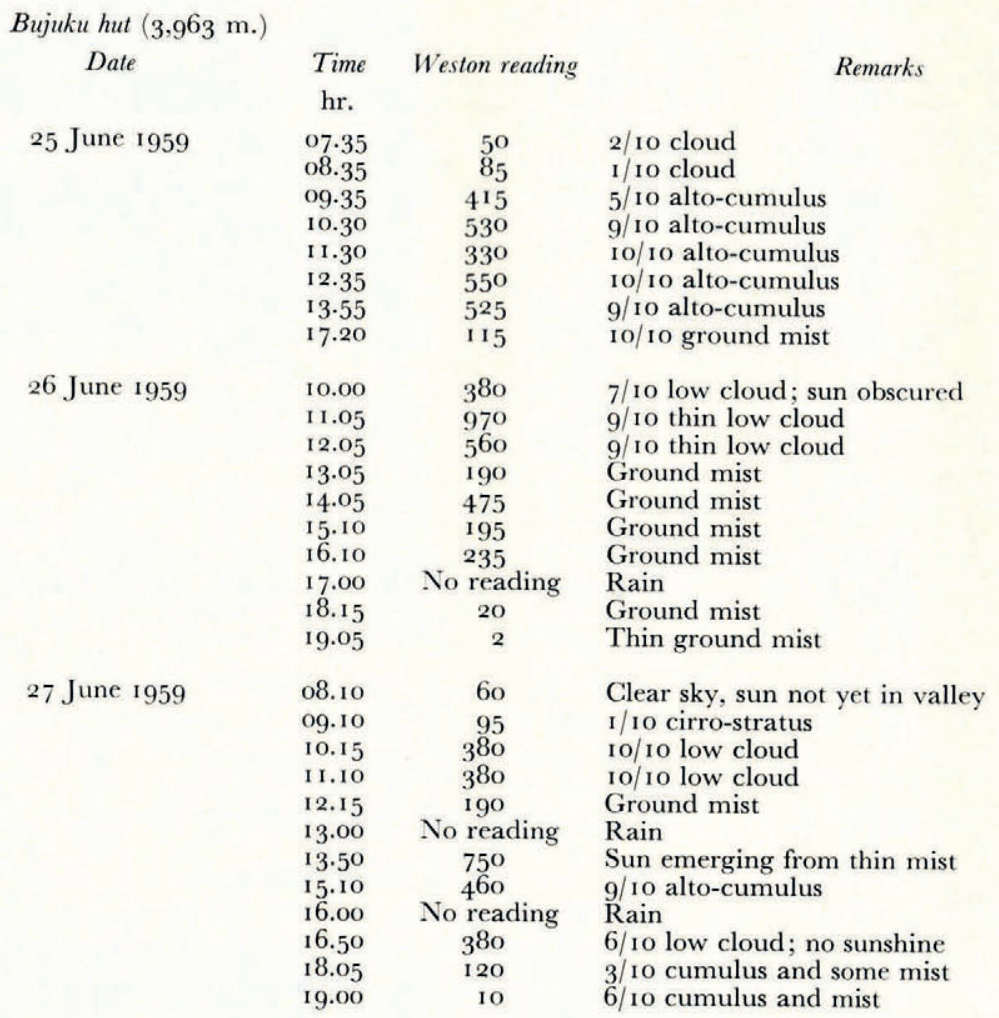


TABLE IV-continued

Speke Glacier snout $(4,393$ m.)

Date Time

$$
\text { Date }
$$

26 June 1959

27 June 1959

Elena huts (4,51 I m.)

I July 1959

\section{Time}

hr.

08.00 09.00 I0.10

I I. 35

12.25

13.37

14.16

I 5.35

16.05

17.05

18.10

07.30

09. 18

IO. 15

12.00

I 4.30

15.45

I 7.15

$18.5^{\circ}$
Weston reading

75
$4^{15}$
$3^{20}$
155
315
415
$9^{1} 10$
165
525
45
30

45

I5 I

415

320

130

65

800

23

$\begin{array}{rr}08.00 & 50 \\ 09.30 & 240 \\ 11.00 & 765 \\ 12.00 & 480 \\ 13.00 & 380 \\ 14.00 & 380 \\ 15.00 & 290 \\ 17.00 & 290 \\ 18.20 & 145 \\ 18.50 & 125\end{array}$

Kitandara hut $(3,993 \mathrm{~m}$. 3o June 1959

16.15
17.25

17.25

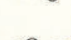

I July 1959

2 July 1959

3 July 1959
08.15

09.05
I 0.15

I0. 15
I 2.00

I 3.30

17.00

I8.55

08.00

09. 15

I 1.00

I 2.00

08.30

09.05

I0.05

I 1.00
${ }_{1} 85$
500

95

6

I5

215

220

I 55

215

35

12

45

255

$1430^{*}$

130

45

I90

660
Remarks

Clear; cloud down at $08.45 \mathrm{hr}$.

Cloud lifted temporarily

Cloud lifted for a few minutes at 1 I .oo hr.

Cloud down

Thick cloud on glacier

Cloud at ground level

7/1o cumulus rising above peaks

Cloud right down

Cloud right down

Io/ Io low cloud

IO/ Io low cloud after a short break

\section{Clear sky}

I/10 cirro-stratus

Cloud at ground level

Cloud at ground level

Io/ Io cumulus, glacier clear

Io/10 cloud at ground level

8/10 cumulus

Low cloud

\author{
Ground mist \\ Ground mist; drizzle \\ Ground mist; drizzle \\ Ground mist \\ Ground mist \\ Ground mist \\ Thick ground mist \\ Thick ground mist \\ Thick ground mist clearing \\ 9/10 cloud
}

* There were only two other measurements recorded in bright sunshine near the middle of the day. They were as follows:

Bujuku hut, 7 July, $14.20 \mathrm{hr}$. Weston reading 1,930 . Clear sun.

Speke Glacier snout, 28 June, $12.30 \mathrm{hr}$. Weston reading $\mathrm{I}, 650$. Sun's disc visible behind 8/10 strato-cumulus. 


\section{Conclusion}

The obvious conclusion to be drawn from all the observations and measurements on the Ruwenzori glaciers is that there is an increasingly rapid deglacierization in progress. The causes of this ice recession on the East African snow peaks during the last century are not fully understood, but if, as seems possible, the glacial recession is on a global scale, then its cause may be of extraterrestrial origin.

Local meteorological records are scanty in East Africa and they do not extend back much more than $5^{\circ}$ years, so that it is not easy to distinguish a localized climatic change. A study of the available rainfall statistics has demonstrated that in the period $1920-49$ there have been significant rainfall trends in East Africa (Sansom, 1952). During the period in question rainfall decreased by as much as $150 \mathrm{~mm}$. on Mount Kenya, but at the same time rainfall in the vicinity of Kilimanjaro and the Ruwenzori appears to have increased by approximately $75 \mathrm{~mm}$. Thus, rainfall variations cannot be advanced as evidence for the general deglacierization of East Africa, although they may have had important local repercussions. Nor does a study of temperature trends provide a satisfactory answer to the problem, for the stations which have long-term records merely exhibit a series of wave-like oscillations since 1915 , the amplitude being of the order $3^{\circ} \mathrm{F}$. ( $2^{\circ} \mathrm{C}$.). If anything, there appears to have been a slightly negative trend of East African mean temperatures since $193^{8}$ (private communication from the Meteorological Department, Entebbe, Uganda). It has been suggested that cloud cover on the Ruwenzori may have been greater during the nineteenth century, and this would certainly have an important effect on the ablation rates in low latitudes if it were true. Attempts have been made to study the effects of differing cloud amounts and their relationship to different air masses (Whittow, I960), but the results, though interesting, are inconclusive when related to the present question of long-term deglacierization. Before a definite conclusion can be reached, it will be necessary to collect far more meteorological statistics from the high mountain areas of East Africa and elsewhere in the Tropics.

\section{Acknowledgements}

The authors are indebted to the Royal Society, the Royal Geographical Society, the Mount Everest Foundation and Makerere University College, Uganda, for the necessary expedition funds and a contribution towards publication costs; to the many members of the expeditions, and in particular F. P. Henderson, C. J. Ball and L. E. Harrison, for their support in the field; to Professor G. Manley in Britain and Professors J. P. Andrews and S. J. K. Baker in East Africa for their help and encouragement.

\section{MS. received 25 January 1962 and in revised form 8 October 1962}

\section{REFERENCES}

Bergström, E. 1955. British Ruwenzori Expedition, I952: glaciological observations - preliminary report. Fournal of Glaciology, Vol. 2, No. 17, p. 468-76.

Busk, D. L. 1954. The southern glaciers of the Stanley group of the Ruwenzori. Geographical Journal, Vol. 120, Pt. 2, p. $137-45$.

Busk, D. L. 1957. The fountain of the sun; unfinished journeys in Ethiopia and the Ruwenzori. London, Parrish.

Chapin, J. P. 1927. Ruwenzori from the west. Natural History, Vol. 27, No. 6, p. 615-27.

Filippi, F. de. 1908. Ruwenzori. A a account of the expedition of H.R.H. Prince Luigi Amedeo of Savoy, Duke of the Abruzzi. London, Constable.

Firmin, K. 1945. Ruwenzori - the Mountains of the Moon. East African Annual, r944-45, p. 24-35.

Fisher, R. B. 1905. On the borders of Pygmy land. London, Marshall Bros.

Freshfield, D. W. 19o6. Towards Ruwenzori. I-II. Alpine Journal, Vol. 23, No. 172, p. 87-98; No. 173 , p. $185-202$.

Grunne, X. de. 1933. Ruwenzori from the west. Alpine fournal, Vol. 45, No. 247, p. 275-89.

Grunne, X. de, and others. 1937. Vers les glaciers de l'Équateur. Le Ruwenzori. Mission scientifique belge, I932, [par] $X$. de Grunne, L. Hauman, L. Burgeon, P. Michot. Bruxelles, R. Dupriez.

Heinzelin, J. de. [1952[a].] Le retrait des glaciers du flanc ouest du massif Stanley (Ruwenzori). Union Géodésique et Géophysique Internationale. Association Internationale d'Hydrologie Scientifique. Assemblée générale de Bruxelles, I95I. Tom. I, p. $203^{-05}$. 
Heinzelin, J. de. 1952 [b]. Glacier recession and periglacial phenomena in the Ruwenzori range (Belgian Congo). Fournal of Glaciology, Vol. 2, No. 12, p. 137-40.

Heinzelin, J. de. 1955. Les stades de recession du glacier Stanley Occidental (Ruwenzori, Congo Belge). Exploration du Parc National Albert, Deuxième Série, Fasc. I, p. I-25.

Heinzelin, J. de, and Mollaret, H. 1956. Biotopes de haute altitude Ruwenzori, 1. Exploration du Parc National Albert, Deuxième Série, Fasc. 3, p. 1-31.

Hicks, P. H. 1947. Mount Gessi of the Ruwenzori range. East African Annual, 1946-47, p. $14-21$.

Humphreys, G. N. 1927. New routes on Ruwenzori. Geographical Journal, Vol. 69, No. 6, p. 516-31.

Johnston, H. H. 1902. The Uganda Protectorate. Vol. 1. London, Hutchinson.

Makerere College Ruwenzori Expedition. 1958[a]. First report: reconnaissance (December 1957-7anuary 1958). Kampala, Department of Geography, Makerere College.

Makerere College Ruwenzori Expedition. I958[b]. Second report: second expedition (June 1958). Kampala, Department of Geography, Makerere College.

Makerere College Ruwenzori Expedition. 1959. Third report: fourth expedition (June-July 1959). Kampala, Department of Geography, Makerere College.

Menzies, I. R. I95 I[a]. Some observations on the glaciology of the Ruwenzori range. Fournal of Glaciology, Vol. I, No. 9 , p. $511-12$.

Menzies, I. R. 195I[b]. The glaciers of Ruwenzori. Uganda Journal, Vol. 15, No. 2, p. $177-8$ I.

Michot, P. 1933. Les traits caractéristiques de la morphologie du Ruwenzori dans leurs relations avec la tectonique du massif. Bulletin de la Société Royale Belge de Géographie, Tom. 57, p. $5^{-1} 3$.

Moore, J. E. S. I901. To the Mountains of the Moon. London, Hurst and Blackett.

Osmaston, H. A. 1961. Notes on the Ruwenzori glaciers. Uganda Journal, Vol. 25, No. 1, p. 99-104.

Sansom, H. W. 1952. The trend of rainfall in East Africa. East African Meteorological Department. Technical Memorandum No. $\mathrm{I}$.

Spink, P. C. 1949. The equatorial glaciers of East Africa. Journal of Glaciology, Vol. I, No. 5, p. $277-8$ I .

Stuhlmann, F. 1894. Mit Emin Pascha ins Herz von Afrika. Berlin, Dietrich Reimer.

Stumpp, A. 1952. Kartierungsarbeiten im Ruwenzorigebirge. Allgemeine Vermessungsnachrichten, 1952, Nr. 6, p. $142-47$.

Synge, P. M. 1937. Mountains of the Moon. London, L. Drummond.

Whittow, J. B. I959. The glaciers of Mount Baker, Ruwenzori. Geographical fournal, Vol. 125, Pts. 3-4, p. 370-79.

Whittow, J. B. 1960 . Some observations on the snowfall of Ruwenzori. Journal of Glaciology, Vol. 3, No. 28 , p. $765-72$.

Whittow, J. B., and Shepherd, A. 1958. The Speke Glacier, Ruwenzori. Uganda fournal, Vol. 23, No. 2, p. I53-6 I.

Willis, B. 1936. East African plateaus and rift valleys. Washington, D.C., Carnegie Institution of Washington. (Carnegie Institution of Washington Publication No. 470.)

Wollaston, A. F. R. I908. From Ruwenzori to the Congo: a naturalist's journey across Africa. London, John Murray. 